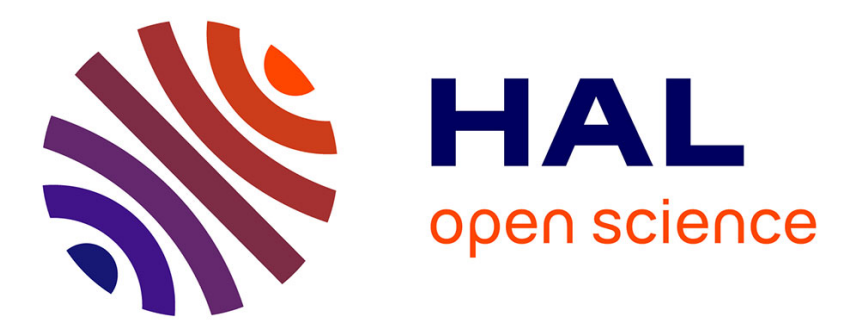

\title{
Cranial anatomy of the Early Triassic trematosaurine Angusaurus (Temnospondyli: Stereospondyli): 3D endocranial insights and phylogenetic implications
}

Meritxell Fernández-Coll, Thomas Arbez, Federico Bernardini, Josep Fortuny

\section{- To cite this version:}

Meritxell Fernández-Coll, Thomas Arbez, Federico Bernardini, Josep Fortuny. Cranial anatomy of the Early Triassic trematosaurine Angusaurus (Temnospondyli: Stereospondyli): 3D endocranial insights and phylogenetic implications. Journal of Iberian Geology, 2019, 45 (2), pp.269-286. 10.1007/s41513018-0064-4 . hal-02188788

\section{HAL Id: hal-02188788 \\ https://hal.sorbonne-universite.fr/hal-02188788}

Submitted on 18 Jul 2019

HAL is a multi-disciplinary open access archive for the deposit and dissemination of scientific research documents, whether they are published or not. The documents may come from teaching and research institutions in France or abroad, or from public or private research centers.
L'archive ouverte pluridisciplinaire HAL, est destinée au dépôt et à la diffusion de documents scientifiques de niveau recherche, publiés ou non, émanant des établissements d'enseignement et de recherche français ou étrangers, des laboratoires publics ou privés. 


\title{
Cranial anatomy of the Early Triassic trematosaurine Angusaurus (Temnospondyli: Stereospondyli): 3D endocranial insights and phylogenetic implications
}

\author{
Meritxell Fernández-Coll ${ }^{1} \cdot$ Thomas Arbez $^{2} \cdot$ Federico Bernardini $^{3,4} \cdot$ Josep Fortuny ${ }^{2,5}$ (D)
}

\begin{abstract}
Background Trematosaurines are a widespread group of early tetrapods (Temnospondyli, Stereospondyli) known from all continents except South America and Antarctica. They radiated rapidly during the Early Triassic just after the End Permian mass extinction and are of interest to understand the recovery of the ecosystems just after extinction. Trematosaurines disappeared during the Late Triassic.

Objective Herein, a re-description of the genus Angusaurus is presented based on a new specimen. This genus is known from the Early Olenekian (Early Triassic) of Russia and comprises four valid species, although the diagnostic characters that deine some of them are vague and controversial.

Methods The new specimen described, using MicroCT scanner and 3D digital modeling, sheds light on the anatomical details of the external and inner cranial structure, and provides new details of the neurocranium as well as the ontogeny of this genus. Results and Discussion A cladistic analysis of trematosaurines (including most trematosauroids) confirms the problematic nature of some Angusaurus species and provides a basis for detailed discussion about the phylogeny of trematosaurines.
\end{abstract}

Keywords Trematosauria $\cdot$ Trematosauroidea $\cdot$ Trematosauridae $\cdot$ Trematosaurinae $\cdot$ Stereospondyli

\section{Resumen}

Antecedentes Los trematosaurinos son un grupo ampliamente distribuido de tetrápodos basales (Temnospondyli, Stereospondyli) conocidos de todos los continentes excepto Sud América y la Antártida. Este grupo se diversificó rápidamente durante el Triásico Inferior justo después de la extinción en masa del Pérmico terminal y son de interés para entender la recuperación de los ecosistemas justo después de la extinción. Los trematosaurinos desaparecieron durante el final del Triásico.

Objetivo En el presente trabajo se presenta una re-descripción del genero Angusaurus basada en un nuevo espécimen. Este género es conocido del Olenekiense Inferior (Triásico Inferior) de Rusia y comprende cuatro especies validas, aunque los caracteres diagnósticos que definen algunos de ellos son vagos y controvertidos.

Métodos El nuevo espécimen descrito, usando un escáner de MicroTomografía y modelado digital 3D, aporta nueva luz sobre detalles craneales anatómicos externos y de la estructura craneana interna y aporta nuevos detalles del neurocráneo así como de la ontogenia de este género.

Resultados y discusión Un análisis cladístico de los trematosaurinos (incluyendo la mayoría de trematosauroideos) confirma la problemática naturaleza de las especies de Angusaurus y aporta las bases para una profunda discusión sobre la filogenia de los trematosaurinos.

Palabras clave Trematosauria $\cdot$ Trematosauroidea $\cdot$ Trematosauridae $\cdot$ Trematosaurinae $\cdot$ Stereospondyli

Electronic supplementary material The online version of this article (https://doi.org/10.1007/s41513-018-0064-4) contains supplementary material, which is available to authorized users.

\section{Introduction}

Temnospondyls are a large group of tetrapods ranging from the Early Carboniferous to the late Early Cretaceous (Schoch 2013). They survived the end-Permian mass extinction and 
during the Early Triassic (Induan) their diversity rapidly increased, although it decreased gradually after the Late Triassic (Milner 1990). One of the most successful clades of temnospondyls are stereospondyls. Their members made their first appearance during the Late Permian and survived until the Early Cretaceous, reaching their maximum diversity during the Early Triassic (Stayton and Ruta 2006), presenting a worldwide distribution. They were predominantly, but not exclusively, aquatic-semiaquatic tetrapods living within a range of habitats from freshwater to coastal and even marine environments. During the beginning of the Early Triassic two stereospondyl groups, trematosauroids and capitosauroids, dominated these ecosystems, some acquiring gigantic sizes (Fortuny et al. 2016). Trematosauroids lived from the Early to the Late Triassic (Hellrung 1987), expanded over Pangaea, and are known from all continents except South America and Antarctica. The phylogenetic relationships within trematosauroids are still debated, but they include few basal trematosauroids (such as Benthosuchus) and a huge clade of trematosaurs divided into two subclades: Trematosaurinae (short-snouted members) and Lonchorhynchinae (long-snouted members; see Welles 1993; Steyer 2002; Schoch 2006; Fortuny et al. 2018 for further discussion).

Most trematosaurs belong to Trematosaurinae. Several trematosaurine taxa have been described, mainly from Central European basins and the Russian Eastern Platform, but also from other European basins (e.g. Spitsbergen), Africa (e.g. Madagascar, South Africa) and Australia. The radiation of trematosaurines during the Early Triassic was rapid, demonstrating the importance of this group in understanding the recovery of the ecosystems just after the End Permian mass extinction.

Herein, the Early Triassic trematosaurine Angusaurus is analyzed and its phylogenetic position addressed. This genus is known from the Russian East Platform and four species have been erected to date based on cranial and mandible specimens (Kuzmin 1935; Getmanov 1982, 1989; Novikov 1990). Based on the description of an undescribed smallsized specimen our aims are: (a) to describe the external anatomy; (b) to describe in detail its neurocranium using MicroCT scanning; (c) the taxonomic study of the analyzed skull to evaluate its taxonomical assessment; and (d) to perform a cladistic analysis of trematosaurids, with particular emphasis on trematosaurines in order to evaluate the phylogenetic position of Angusaurus and shed new light on the phylogeny of trematosaurines and its paleobiogeographical implications.

Institutional Abbreviations-MNHN: Museum National d'Histoire Naturelle, Paris, France; PIN: Paleontological Institute, Moscow, Russian Federation; SMNS, Staatliches Museum für Naturkunde in Stuttgart, Germany.

\section{Materials and methods}

The analyzed specimen (SMNS 81782) is stored at the Staatliches Museum für Naturkunde in Stuttgart, Germany and corresponds to an almost complete skull. It has been reported (not figured nor described) by Schoch and Milner (2000) and referred to A. succedaneus. The specimen was recovered in the region of Rybinsk, Russia. This area is well-known geologically and paleontologically, located in the upper part of the Volga River. The sediments consists of lacustrine marls dated as Olenekian, Early Triassic (Grauvogel-Stamm and Ash 2005). The region of the upper Vetluga River, one of the Volga effluents, is well known for the presence of temnospondyl remains: capitosaurs such as Wetlugasaurus, trematosauroids such as Benthosuchus and trematosaurids as Thoosuchus, Angusaurus and Trematotegmen, have all been found in the Upper Vetluga formations (Sennikov 1996).

The specimen was scanned using X-ray computed microtomography (microCT) at the Multidisciplinary Lab (MLAB) of the "Abdus Salam" International Centre for Theoretical Physics (ICTP) in Trieste, Italy. See Tuniz et al. (2013) for further details about the equipment. Due to the size of the sample and the reduced size of the microCT scan detector, it was required to scan it in two parts: one from the anterior end of the snout to the posterior edge of the prefrontal, and the second one from the posterior edge of the prefrontal to the occipital condyles. The parameters for each part of the skull were the same: $149 \mathrm{kV}$ voltage, $50 \mu \mathrm{A}$ current with $0.1 \mathrm{~mm}$ filter of copper. A total of 1800 X-ray slices were obtained with a voxel resolution of $35.71 \mu \mathrm{m}$.

Raw data from each scan was imported (as stack of TIFF 8-bit files) to Avizo 7.0 to generate a 3D surface from the microCT images. Data produced by segmentation in Avizo were exported to the programs Rhinoceros 5.0 and 3matic 9.0 for PDF 3-D creation (see supplementary information).

The direct study of the specimen complements the digital part of its analysis. Measurements of some areas of the skull were taken with a digital calliper (Electro DH, model 60.205 , resolution of $0.01 \mathrm{~mm}$ ).

Anatomical abbreviations ans, anterior sulcus; apv, anterior palatal vacuity; br, basipterygoid ramus; ch, choana; cls, cristae laterosphenoidales; co, crista oblica; cp, cultriform process; ct, chorda tympani; cv, columna verticalis; f, foramen; fm, foramen magnum; is, infraorbital sulcus; iv, interpterygoid vacuity; js, jugal sulcus; jf, jugular foramen; la, lamina ascendens; ld, lamina descendens; fl, flexura lacrimalis; lp, lamellar process; mf, Meckelian foramen; na, naris; oc, occipital condyle; ocs, occipital sulcus; pap, paroccipital process; pf, pineal foramen; pl, processus lamellosus; plf, palatoquadrate fissure; pr, palatine ramus; psm, processus 
submedullaris; pst, processus subtympanicus; ptf, postemporal fenestra; qr, quadrate ramus; sos, supraorbital sulcus; sv, supratemporal vacuity; ts, temporal sulcus. Bones: AN, angular; COR, coronoid; D, dentary; ECPT, ectopterygoid; EO, exoccipital; F, frontal; ICOR, intercoronoid; J, jugal; L, lacrimal; MX, maxilla; N, nasal; P, parietal; PAR, prearticular; PCOR, precoronoid; PL, palatine; PMX, premaxilla; PO, postorbital; POF, postfrontal; PP, postparietal; PRF, prefrontal; PS, parasphenoid; PSP, postsplenial; PT, pterygoid; Q, quadrate; QJ, quadratojugal; SA, surangular; SP, splenial SQ, squamosal; ST, supratemporal; T, tabular; VO, vomer.

\section{Systematic paleontology}

Temnospondyli Zittel 1887-1890

Stereospondyli Zittel 1887-1890

Trematosauria Romer, 1947 sensu Yates and Warren 2000 Trematosauroidea Säve-Söderbergh 1935 sensu Schoch 2013

Trematosauridae Watson 1919

Trematosaurinae Watson 1919, sensu Fortuny et al. 2018

Angusaurus Getmanov 1989

Angusaurus cf. tsylmensis Getmanov 1989

Type species.-Angusaurus dentatus

Valid species.-Angusaurus dentatus, Angusaurus weidenbaumi, Angusaurus succedaneus, Angusaurus tsylmensis.
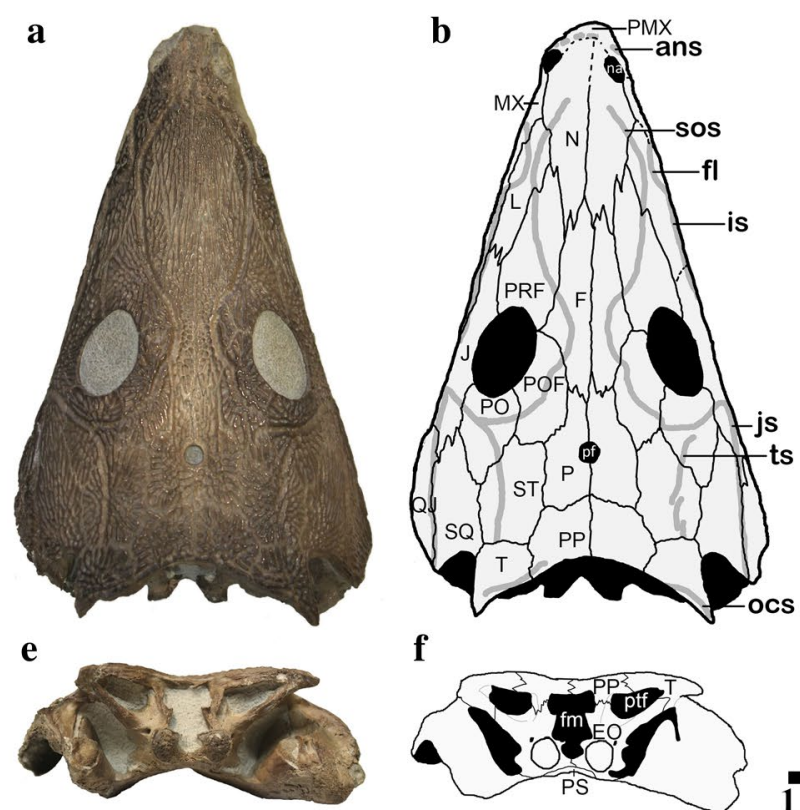

f

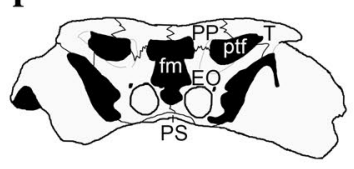

Definition All taxa sharing a more recent common ancestor with Angusaurus dentatus than with Thoosuchus yakovlevi. Emended diagnosis Skull up to $200 \mathrm{~mm}$ long. Oval orbits, laterally emplaced. Elongated postorbitals and postfrontals. Interchoanal tooth row strongly reduced. Ventral opening of the orbit in the mid part. Postglenoid process of the mandible elongated. Medial process of supraangular well developed. Type horizon Vetlugian Horizon with two subhorizons: Sludkinsk Subhorizon, early Early Olenekian (Early Triassic) for Angusaurus dentatus, Angusaurus succedaneus, Angusaurus weidenbaumi.Ustmylskian Subhorizon, late Early Olenekian (Early Triassic) for Angusaurus tsylmensis. Locus typicus Left shore of Samara river at Dolgiy Yar, Buzulukskij Rajon, Orenburgskaya Oblast (A. dentatus); Chapayevsk, Alexeyevka District, Kuybyshevskaja Oblast (A. succedaneus); Pleas near Kineshma, Furmanovskij Rajon, Ivanovskaya Oblast (A. weidenbaumi); Mala locality, Tsyl'ma River region, Komi Republic (A. tsylmensis). All of them eastern European Russia.

\section{Description}

\subsection{Preservation}

The specimen (SMNS 81782) has a narrow, elongated and triangular-shaped skull (Fig. 1). Its maximum length is $112 \mathrm{~mm}$ and it has a maximum width of $74 \mathrm{~mm}$
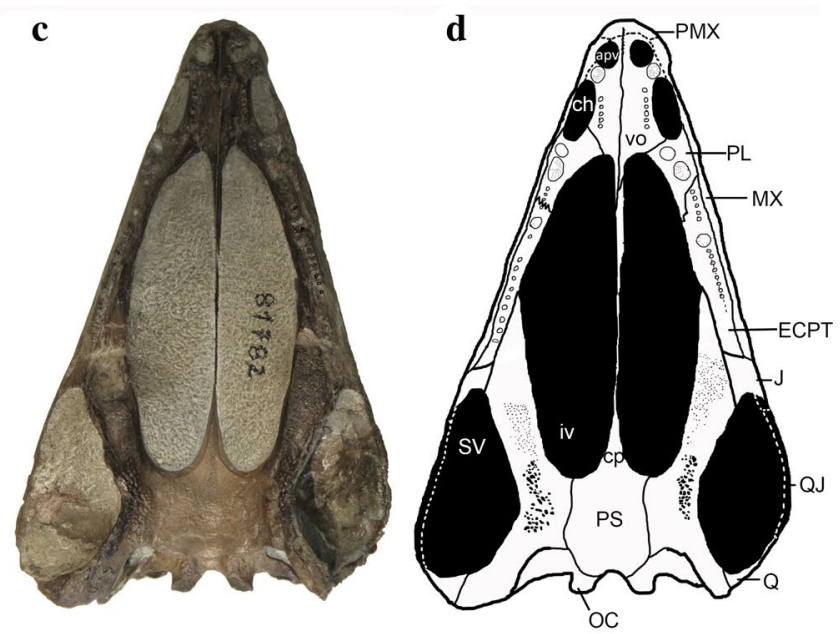

g

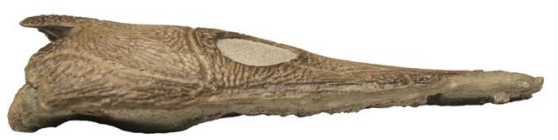

Fig. 1 Angusaurus cf. tsylmensis. Early Olenekian (Lower Triassic) of Russia (SMNS 81782) in dorsal (a, b), ventral (c, d), occipital (e, f) and lateral view (g) 
Fig. 2 3D model of Angusaurus cf. tsylmensis (SMNS 81782). Matrix removed in dorsal (a), ventral (b), lateral (c) and occipital (d) views
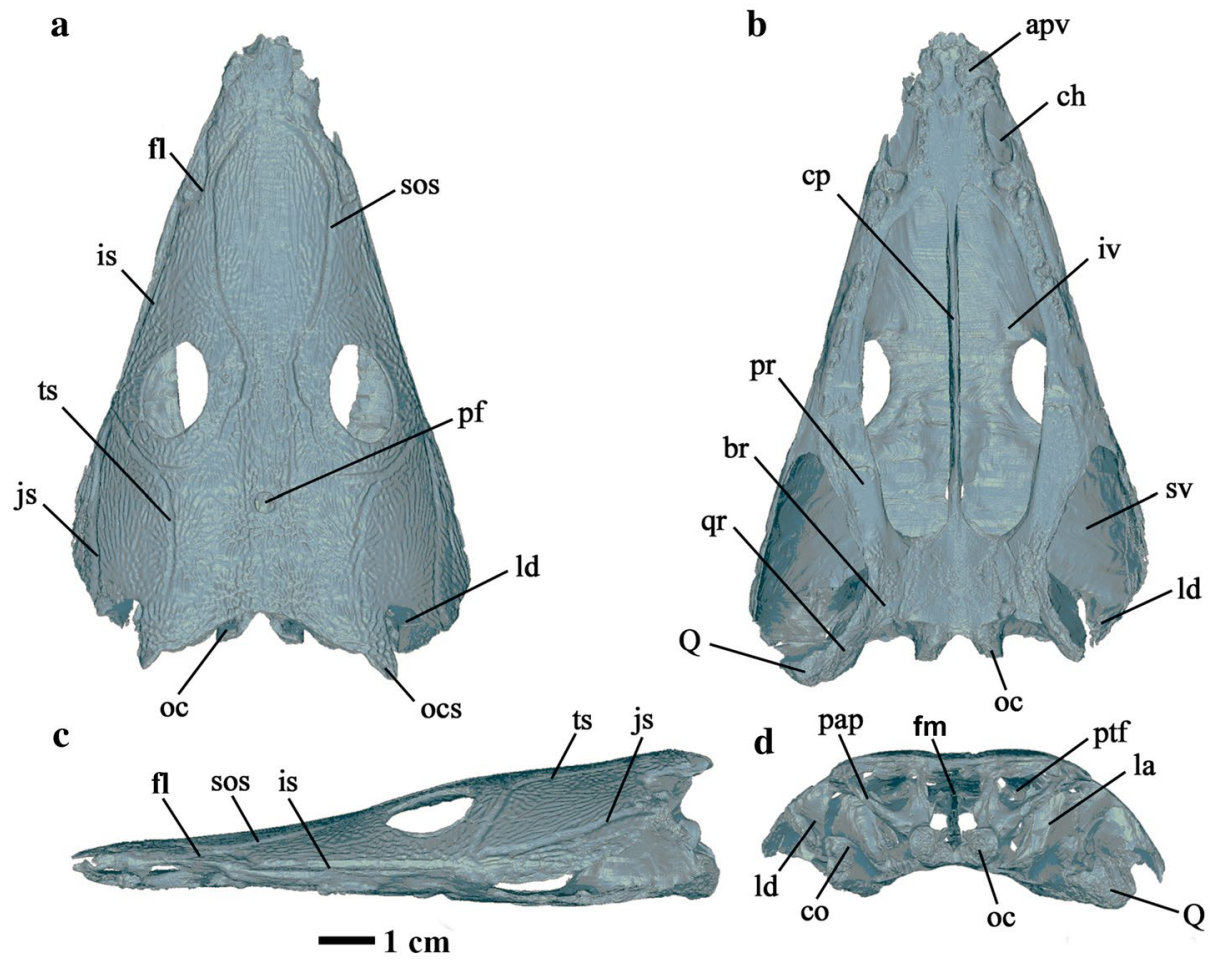

(supplementary material-Table). The specimen is a nearly complete and well-preserved skull (Figs. 1,2). The anteriormost part of the snout, formed by the maxilla, premaxilla and part of the nasal bone, as well as the cheek region, comprising the jugal and the quadratojugal, is the only slightly damaged part of the specimen that precludes proper observation. There is no evident damage due to mechanical transport in the skull. The posterior margin of the skull, formed by the tabulars and the postparietals, is slightly concave (Figs. 1, 2).

\subsection{Lateral line system and ornamentation}

Between most of the bones the sutures are clearly visible, while on the anterior part of the snout - as previously mentioned - and on the cheek region they are less well defined due to damage. Also, on some bones (nasal, premaxilla, maxilla) the ornamentation and the sensorial sulci are difficult to discern with confidence. Sensorial sulci are generally continuous and strongly marked (Figs. 1,2). The anterior sulcus, generally found at the anterior end of the snout, close to the naris, is faintly present. The supraorbital sulcus is continuous with an S-shaped morphology and passes through the nasal, lacrimal, prefrontal, frontal, postfrontal, and postorbital bones, where it connects with the jugal and the temporal sulci, the latter found on the left side (but not present on the right side). The infraorbital sulcus goes mainly through the maxilla, and in the lacrimal bone it forms a flexure, the flexura lacrimalis, that is faintly marked and rounded. The jugal sulcus is continuous and goes through the jugal, following the quadratojugal-squamosal suture in posterior direction (Fig. 2). The temporal sulcus contacts the jugal sulcus in the jugal and goes through the postorbitals and the supratemporals, contacting the supraorbital sulcus in the postorbital bone (clearly on the left side and almost contacting it on the right side). The occipital sulcus is faintly present on the left side, from the tabular horn to up to one-third of the postparietal. On the right side, the occipital sulcus is only visible on the tabular bone. On the right side of the skull roof, part of the supraorbital, temporal and occipital sulci are slightly marked. On this side, the supraorbital sulcus is less evident through the postfrontal while the temporal sulcus is less evident through the supratemporal. On the other hand, the occipital sulcus its less evident on the postparietal bone.

The skull roof has a prominent ornamentation with some areas presenting ridge-groove ornamentation, indicating intensive growth on the skull (Damiani and Yates 2003). The bones on the skull roof are characterized by dermal bone with polygonal sculpture in the ossification centre and radial sculpture in the peripheral region of the bone. The polygonal sculpture consists of polygonal grooves separated by thin ridges, while the radial sculpture is characterized by elongated furrows and ridges that radiate in opposite direction from the ossification centre of the bone (Witzmann et al. 2010). The sculpture is not homogenous along the entire skull roof. Suture morphology was identified thanks to micro-CT images. Most sutures are groove-like (sensu 
Kathe 1999), but nonetheless some sutures present on the parietal and supratemporal bones are shelf-like.

\subsection{Skull roof}

The premaxilla and the maxilla are anteroposteriorly elongated but badly preserved anteriorly, precluding assessment of the morphology of the anteriormost part of the snout. The nasal bones are more elongated than the premaxilla. The premaxilla-nasal suture morphology cannot be discerned due to damage. The nostrils, situated at the tip of the snout, are oval, laterally positioned, and have a length between 8 and $9 \mathrm{~mm}$. This measurement is approximate because the left one is badly preserved. The nostril borders are formed by the premaxilla, the nasal and the maxilla. There is no trace of a septomaxilla, although its presence cannot be completely discarded due to bad preservation. The lacrimal is present, with the supraorbital and infraorbital sulci passing through it. The latter sulcus includes the flexura lacrimalis. The prefrontal connects with the postfrontal, frontal, nasal, lacrimal and jugal bones. The prefrontal is longer than wide, being wider in its posterior part. The jugal is long, forming part of the orbital rim, and representing most of the orbital margin (35\%). The rest of bones that form the orbital margin (postorbital, postfrontal, prefrontal, and jugal) occupy a slightly smaller part of the contour, around $20 \%$ each (Fig. 1). The frontal is one of the longest bones of the skull roof with a maximum length of $40.1 \mathrm{~mm}$ (total length of the skull is $112 \mathrm{~mm}$ ). It is followed by the nasal, which is approximately $38.3 \mathrm{~mm}$ in length. The frontal does not contact the orbital margin, a characteristic found in other stereospondyls.

The orbits are oval and large in size, $19.1 \mathrm{~mm}$ long (right) and almost $18 \mathrm{~mm}$ long (left), around $16.6 \%$ of the total preserved dorsal midline length. The orbits are placed in the posterior half of the skull and are lateralized, located near the edge of the skull. The interorbital distance is $23.3 \mathrm{~mm}$ (supplementary material-Table). There is a pronounced depression between the two orbits, formed by part of the postfrontal and frontal bones. The ventral opening of the orbits is placed on the posterior half of the interpterygoid vacuities. The shape of the postorbital bone is raindrop-like, being posteriorly elongated. The supratemporal is rectangular and contacts the tabular, postparietal, parietal, postfrontal, postorbital and squamosal bones. The postfrontal is also rectangular. The quadratojugal is elongate and narrower than its adjacent bones. The quadrate condyles are anterior to the exoccipital condyles. The squamosal is longer than wide and articulates with the supratemporal, postorbital and quadratojugal bones. The parietal is elongate and contacts the postparietal, supratemporal, postfrontal and frontal. The pineal foramen is circular and large, with a diameter of almost $4 \mathrm{~mm}$. It is situated in a posterior position between both parietals, $8.7 \mathrm{~mm}$ posterior to the orbits (supplementary
material-Table). The tabular is triangular, with a short, pointed and poorly-developed horn (Figs. 1, 2). The tabular and squamosal bones conform an open and deep otic notch. The postparietal is slightly wider than long.

\subsection{Palate}

In ventral view, the palatal region of Angusaurus is similar to Thoosuchus (Damiani and Yates 2003), although some differences deserve special attention (Figs. 1, 2). The premaxilla-vomer suture possibly reaches the anterior margin of the anteropalatal vacuity (or fenestra sensu Schoch and Milner 2000), or ends really close to it. These vacuities (Fig. 1) are rounded and have a diameter of $5 \mathrm{~mm}$ (right) and $4.9 \mathrm{~mm}$ (left). The vomer-palatine suture is located on the posterior part of the choana. The choanae are oval, both $11.9 \mathrm{~mm}$ on the long axis, and placed on the lateral margin of the snout. The maxilla is very elongated and contacts the vomer, palatine, ectopterygoid and jugal bones. The palatine contacts the vomer, ectopterygoid, and maxilla. The edge of the palatine forms part of the interpterygoid vacuity and the choana (Figs. 1, 2). The palatine is adjacent to the ectopterygoid posteriorly. The ectopterygoid bears some dentition, mainly anteriorly and on the central region. The ectopterygoid contacts the maxilla laterally, the pterygoid posteriomedially, and the jugal dorsolaterally. The ectopterygoid forms the central part of the margin of the interpterygoid vacuities.

The pterygoid is tri-radiate, with a palatine, basipterygoid, and quadrate rami. The pterygoid has no contact with the exoccipital. From the anterior part of the quadrate ramus to the posterior part of the palatine ramus, the lateral border of the pterygoid bears a strip of polygonal ornamentation. Almost the entire ventral surface of the palatine ramus presents a shagreen field except for its most posterolateral part, as previously mentioned. The palatine ramus forms a long, wide and thick sheet of bone. It is anterolaterally directed, with the anterior extremity contacting the ectopterygoid and the jugal. On the anterior tip of both rami a part of the ventral side is missing, creating an empty space. On the left ramus, a small patch of dot-shaped ornamentation anterior to the above-mentioned empty space indicates the anterior limit of the pterygoid. In anterior direction, the rami become slightly wider until their contact with the jugal. Then, their lateral borders become straight and anteriorly directed. The medial edge of each ramus forms the posterior half of the lateral border of the interpterygoid vacuity. It is slightly curved near the basipterygoid ramus and then become nearly straight anteriorly.

The basipterygoid ramus is very short and laterally wide compared to the other rami. On the medial side it has a complex, tight and dorsoventrally elongated suture with the parasphenoid bone, only visible from the ventral side. A deep and well-delimited subconical depression, the conical recess, 
is visible on the dorsal portion of this branch. This depression is laterally delimited by the anterior base of the lamina ascendens and posteriorly by the crista parapterygoidea of the parasphenoid. This is a similar condition to that found in Lyrocephaliscus euri (Mazin and Janvier 1983 and personal observations of T.A. on MNHN F SVT 520), both in terms of shape and location on the basipterygoid ramus.

On the ventral surface of each basipterygoid ramus, a pair of grooves is visible, with an anterior one reaching the interpterygoid fenestra and a posterior one reaching the posterior border of the basipterygoid ramus (Fig. 1,2). These grooves are nearly straight, with an antero-posterior orientation, and being between 3 and $8 \mathrm{~mm}$ wide. In addition, based on microCT data, the anterior one is connected with the posterior one by a canal inside the bone. Similar grooves are found in several species of temnospondyls, running through the whole length of the basipterygoid rami (e.g. Lyrocephaliscus euri, Mazin and Janvier 1983; Thoosuchus yakovlevi; personal observations of T.A. on specimen SMNS 58880; Trematolestes hagdorni, Schoch 2006).

The quadrate ramus of the pterygoid forms a bony blade, about two times shorter than the palatine ramus. It shares a tight suture with the quadrate (but the left quadrate is missing) and it is dorsally in contact with the lamina ascendens. The quadrate ramus is slightly inclined medially and transversally oriented. The lateral edge of this ramus is concave and forms the posteromedial part of the subtemporal vacuity.

The lamina ascendens of the pterygoid is a slender, subvertical bony lamella, slightly thicker anteriorly. It medially delimits the columellar cavity in extending the lamina descendens of the squamosal, but these two laminae remain separated by a space, the palatoquadrate fissure. This structure lies on the quadrate and the basipterygoid rami with a transversal orientation except for its anterior tip, which points medially. At the level where the lamina ascendens contacts the quadrate ramus, a crest is present on the medial side, called 'crista obliqua' by Bystrow and Efremov (1940: fig. 5). It delimits a large, long and shallow canal on the medial side of the lamina ascendens.

The ventral surface of the pterygoid presents three kinds of ornamentation. In ventral view, the medial part of the basipterygoid ramus and the margin delimiting the interpterygoid vacuities are smoothed. This ornamentation pattern on the ventral surface of the pterygoid is also found in several trematosaurs (e.g. Thoosuchus yakovlevi, Damiani and Yates 2003; Lyrocephaliscus euri, Mazin and Janvier 1983 and personal observations of T.A. on MNHN F SVT 520; Trematosaurus galae, Novikov 2010), presenting variation in the relative extension of the ornamentation.

The parasphenoid is divided in two parts: the cultriform process anteriorly and the basal plate posteriorly. The cultriform process is a long and narrow rod, laterally compressed, connecting the anterior part of the basal plate to the vomers.
It makes the separation between the two interpterygoid vacuities.

On the dorsal side of the cultriform process, two crests, the 'cristae laterosphenoidales' sensu Schoch (1999) are visible. They are more marked in the posterior part of the cultriform process. The ventral side of the cultriform process is convex in almost its entire length, with a strong lateral compression that gives a "knife-edge" shape to the cultriform process.

The basal plate of the parasphenoid is almost rectangular (length of $18.1 \mathrm{~mm}$ and width of $15.3 \mathrm{~mm}$ ) with a pointed anterior side and a posterior projection (only visible in ventral view because it is covered by the exoccipital in dorsal view). Laterally, the basal plate shares a complex suture with the pterygoids, a typical stereospondyl character (e.g. Yates and Warren 2000), and posteriorly with the exoccipital.

The anterior margin of the basal plate of the parasphenoid is slightly concave and forms the posterior limit of the interpterygoid vacuities and the beginning of the cultriform process.

On the dorsal surface of the basal plate of the parasphenoid, two crests are posterolaterally located, named 'cristae parapterygoideae' sensu Bystrow and Efremov (1940: fig. 9A). They have a transverse orientation, like in Lyrocephaliscus euri (Mazin and Janvier 1983: fig. 7; personal observations of T.A. on MNHN F SVT 520).

Lateral to the ventral side of the posterior projection there is a pair of well-separated muscular pockets, as in Thoosuchus yakovlevi (Damiani and Yates 2003): they show a curved anterior border, weakly marked, and open posteriorly.

Regarding the interpterygoid vacuities, they are placed in middle palatal position and occupy more than half of the palate. Each vacuity forms an elongated oval with a length of $63 \mathrm{~mm}$ (right one) and $64.1 \mathrm{~mm}$ (left one) and a width of 16.2 and $15.3 \mathrm{~mm}$ respectively. The anterior margin of the interpterygoid vacuities is more pointed than the posterior one.

The subtemporal vacuity is oval with an elongated anterior projection, more pointed than the posterior end of the vacuity. Its total length is $37.6 \mathrm{~mm}$ (right), and $34.6 \mathrm{~mm}$ (left) and maximum width of $19.3 \mathrm{~mm}$ (right) and $18.6 \mathrm{~mm}$ (left). The margins of this vacuity are formed by the pterygoid, which forms the major part of it, the jugal, the quadratojugal and the quadrate. The jugal, the quadratojugal and the quadrate are difficult to observe from this view because they are broken.

\subsection{Dentition}

The dentition is characterized by small teeth, uniform in morphology and size, and six fangs that are bigger than the other teeth. These fangs are usually aligned with rows of small teeth. Both of the fangs and the smaller teeth are 
labyrinthodont. There is one fang of about $5 \mathrm{~mm}$ in diameter between each anterior palatal vacuity and the choana. This fang, placed on the vomer, precedes a row of between 5 and 7 small teeth (Figs. 1,2) that surrounds the internal border of each choana. The exact number of teeth that forms the row is difficult to determinate due to poor preservation. Between the two vomers, closely placed on the upper part of the choana, there is a slight bone elevation with a V-shaped morphology. The presence of teeth in this area is doubtful but cannot be discarded. There are two additional fangs on the palatines. One palatine fang is lost. The other palatine fang, with a diameter of about $4 \mathrm{~mm}$, is followed by a row of 4-6 small teeth. After this row of teeth, on the ectopterygoid, there is another badly-preserved fang. This fang is closely placed to a last row of small teeth that goes through the ectopterygoid. This row is longer than the previous ones but the exact number of teeth cannot be assessed.

\subsection{Occipital region}

The exoccipital is formed by the columna verticalis, bearing the articular condyle, and four processes: the processus submedullaris, the processus lamellosus, the processus paroticus and the processus subtympanicus (Figs. 1, 2, 3). The exoccipital delimits two openings on the skull roof: the foramen magnum has a keyhole shape $(14 \mathrm{~mm} \times 9 \mathrm{~mm}$ at maximum size) as in Thoosuchus yakovlevi, and a postemporal fenestra with an isosceles subtriangular shape with the tip laterally oriented $(6 \mathrm{~mm}$ in height $\times 11 \mathrm{~mm}$ in width for the right one and $6 \mathrm{~mm} \times 10 \mathrm{~mm}$ for the left one). For this postemporal fenestra, the shape is the same as in Thoosuchus yakovlevi, although it is larger in Angusaurus. The size of the postemporal fenestra corresponds to $33 \%$ of the skull height and 26\% of the skull length in Angusaurus, against 20 and 22\% respectively in Thoosuchus yakovlevi (personal observations of T.A. on specimen SMNS 58880). Skull height is measured as the distance between the skull roof and the base of the parasphenoid at the level of the suture between the two postparietals, whereas skull length corresponds to the distance between the two tabular horns (since a part of the left cheek is missing in Angusaurus, the distance between the two cheeks was not used). Once again, Angusaurus and Thoosuchus yakovlevi present similar skull shape.

The columna verticalis contacts a posterior column-like projection of the postparietal dorsally. Beginning from the ventral side, the suture between the exoccipital and the postparietal is located at three quarters of the occipital height (Fig. 1e, f, 3c).

The processus submedullaris is located medially on the columna verticalis, at one-third of the height of the exoccipital (Fig. 3a). The dorsal surface of the processus submedullaris is concave with a truncated oval shape but the anterior border is straight, similar to Benthosuchus sushkini (Bystrow and Efremov 1940: fig. 11).

The processus lamellosus is located above the processus submedullaris and medial to the columna verticalis, at around mid-height of the foramen magnum. It is relatively poorly developed compared to Benthosuchus sushkini (Bystrow and Efremov 1940: fig. 11). The dorsal surface of this process is concave with an oval shape.

The processus paroticus is projects dorsolaterally from the columna verticalis and forms half of the ventral part of the paroccipital process with the descending flange of the tabular. Posterolaterally, a wide foramen is present as in Benthosuchus sushkini (Bystrow and Efremov 1940: fig. 11) or Lyrocephaliscus euri (Mazin and Janvier 1983: fig. 4.)

The processus subtympanicus is an anterolaterally-projected sheet of bone. It is rectangular, but the left one has a rounded anterior extremity that makes it longer than the right one.

The occipital condyles lie in posteromedial position in relation to the columna verticalis. They are as high as wide and well separated from each other. The posterior and medial surfaces are rough.

On the anterior side of the exoccipital, between the base of the processus lamellosus and paroticus, there is a weak rounded depression. Due to this emplacement and by comparison with Stanocephalosaurus amenasensis (Arbez et al. 2017), it could represent the opisthotic bone.

\subsection{Preservation of internal structures}

Unfortunately, the stapes, otic capsule, epipterygoid, sphenethmoid and basisphenoid are not preserved in SMNS 81782. However, this lack of preservation is not surprising, since the inner structures of stereospondyls are generally poorly ossified, likely cartilaginous, and thus rarely preserved in the fossil record. In trematosaurs, the sphenethmoid is only present in Aphaneramma sp. (SäveSöderbergh 1936) and Benthosuchus sushkini (Bystrow and Efremov 1940), and only Aphaneramma sp. is known to have a preserved basisphenoid (Säve-Söderbergh 1936).

Moreover, in species where the stapes, the otic capsule and the epipterygoid are preserved, these bones possess few and slight contacts with surrounding bones. For example, in $S$. amenasensis the epipterygoid is only linked to the pterygoid and likely by a cartilaginous contact (Arbez et al. 2017). As explained above, because of their weak ossification these elements are easily lost during fossilisation.

\subsection{Phylogenetic analyses}

The phylogenetic position of the genus including all species of Angusaurus was assessed via cladistic analyses. We used the data matrix of Fortuny et al. (2018), which is based 
Fig. 3 3D model of Angusaurus cf. tsylmensis (SMNS 81782). Neurocranium and inner parts (a), oblique view of the occiput (b) and interpretative drawing of the oblique view (c)
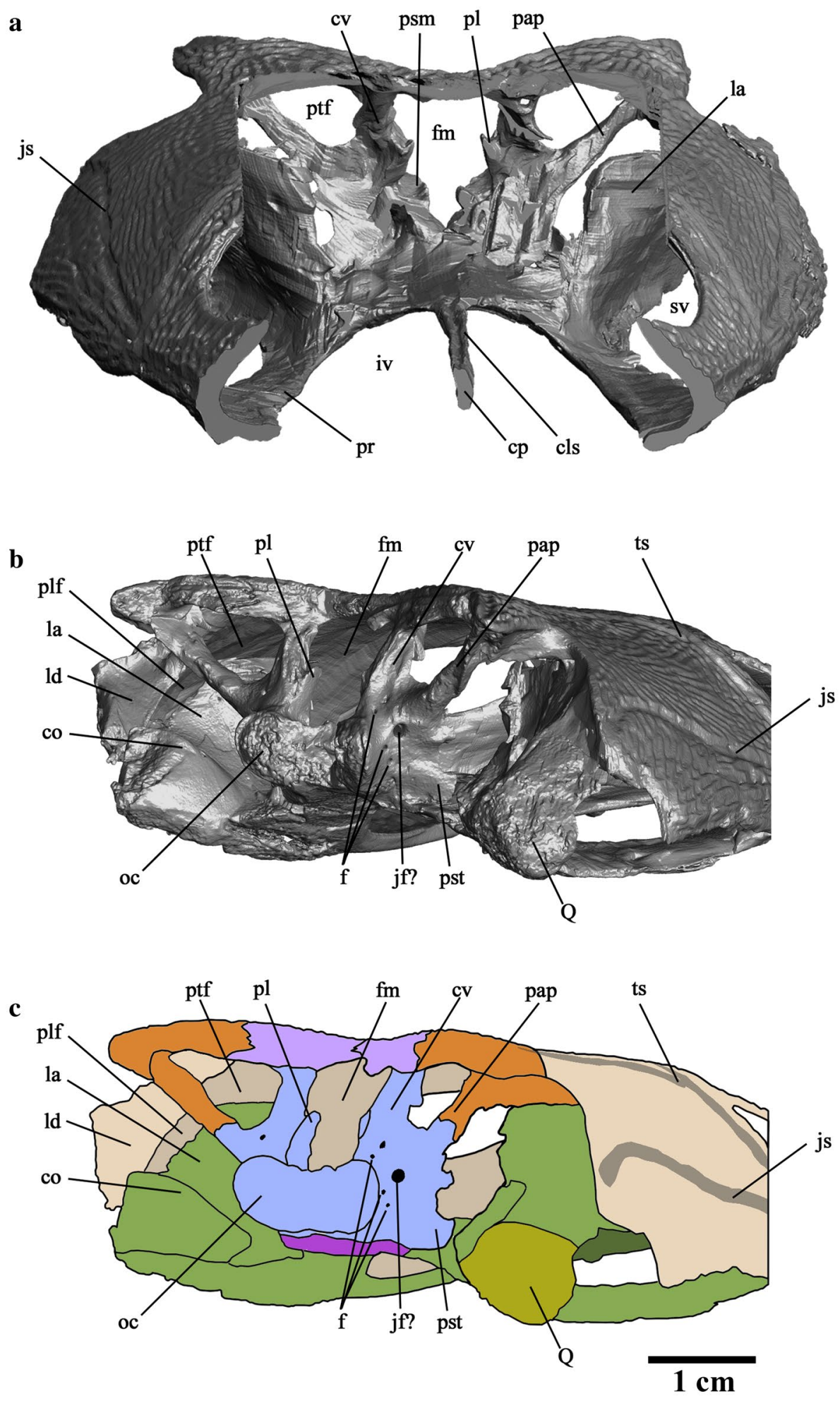

on Steyer (2002), but includes some coding changes due to observation of new specimens as well as additional taxa. Herein, we added two more taxa (Syrtosuchus samarensis, Prothoosuchus blomi) based on the literature (Getmanov 1989; Novikov 2016). We tested the genus Angusaurus in two different analyses. In one of the analyses, we coded the three species A. dentatus, A. succedaneus and A. tsylmensis separately, while in the second analysis we coded all three Angusaurus species as a group (labeled as Angusaurus spp.). All the terminal taxa were considered at the specific level 
(except for the Angusaurus cluster). Onchiodon frossardi and Archegosaurus decheni were considered as outgroups. In total, 25 terminal taxa and 69 characters were analyzed (see supplementary material for the data matrix) using the software PAUP 4.0 beta for PC (Swofford 2001). All characters were considered equally weighted and unordered. Eight characters from the data matrix were found to be uninformative, and excluded from the analyses. These excluded characters are (same as in the previous published analysis, Fortuny et al. 2018): 16 (frontal contact orbit), 17 (interfrontal), 28 (vomer contact maxilla), 46 (paraquadrate foramen), 56 (stapes morphology), 62 (parasymphysial tooth row), 63 (denticles coronoids) and 67 (crista articularis). We performed a heuristic search of 10,000 replicates with simple addition sequence and only one tree retained at each step during stepwise addition. Tree-Bisection-Reconnection (TBR) branch swapping was performed and zero-length branches were collapsed to yield polytomies.

The analysis treating the three Angusaurus species ( $A$. dentatus, A. succedaneus, A. tsylmensis) as separate species, recovered five most parsimonious trees (MPT) of 202 steps (CI 0.396, RI 0.4831, RC 0.1913) (Fig. 4). The consistency index is low and reveals a high amount of homoplasy in trematosaur evolution. A bootstrap analysis with 1000

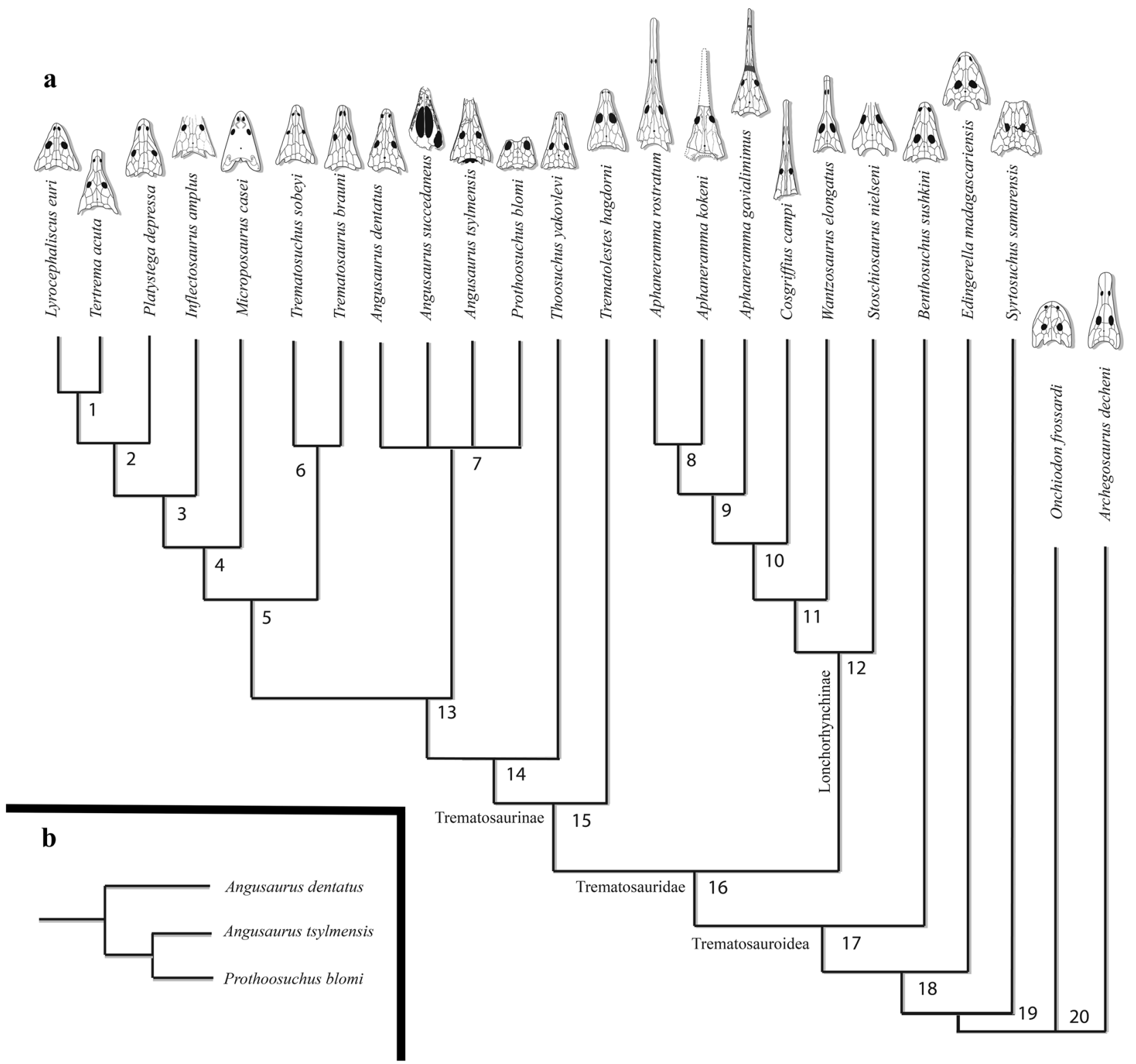

Fig. 4 Phylogenetic position of Angusaurus within the Trematosauroidea clade. Strict consensus tree from the five Most Parsimonius Trees (MPT) recovered under a heuristic analysis (see text) (a).
Results for Angusaurus taxa if A. succedaneus is removed from the analysis, rest of tree typology identical (b). Node numbers refer to clades (see text and supplementary material) 
replicates also reveals relatively low support, with only two clades with support over 50\% (Stereospondyli: $61 \%$ and Aphaneramma rostratum + Aphaneramma kokeni: $51 \%$ ). The monophyletic Lonchorhynchinae (node 12) is supported by four synapomorphies: orbits facing laterally [5(1)], knifeedged cultriform process [38(2)], absence of the crista muscularis of the parasphenoid [42(0)], and carotid canal visible on the ventral surface of the parasphenoid [43(1)].

In this analysis, Lonchorhynchinae is the sister-taxon of Trematosaurinae (node 15), as found by Steyer (2002) and Fortuny et al. (2018). The Trematosaurinae clade is composed by the same taxa as in previously recovered trees (Fortuny et al. 2018), but with some taxa in different positions (see below). Trematosaurinae is supported by twelve synapomorphies: orbits facing laterally [5(1)], nostril in lateral position [9(1)], pineal large relative to the size of the skull roof [11(1)], frontal extended behind orbit [15(1)], premaxilla/nasal suture straight [24(1)], ventral opening of the orbit in the anterior half of the interpterygoid vacuity [27(2)], presence of paired anteropalatal vacuities [31(2)], anteropalatal vacuities between the premaxilla/vomerine suture [32(1)], knife-edged cultriform process of the parasphenoid [38(2)], absence of the crista muscularis of the parasphenoid [42(0)], absence of the crista falciformis of the squamosal, in occipital view [53(0)], and Meckelian foramen elongate [65(1)]. The clade joining Trematosaurinae and Lonchorhynchinae is the Trematosauridae (clade 16). This clade is supported by five synapomorphies: nostril ovoid [8(1)], otic notch deep and open [20(1)], anteropalatal vacuities between the premaxilla/vomerine suture. [32(1)], occipital condyles widely separated from each other [50(0)], and welldeveloped crista medialis [66(1)]. As previously recovered by Fortuny et al. (2018), Trematosauridae and Benthosuchus sushkini form the clade Trematosauroidea (node 17), which is supported by ten synapomorphies: small orbit [4(1)], quadrate condyle anterior to the occipital condyle [22(1)], interpterygoid vacuity not widened at all [33(2)], anterior branch of the pterygoid entirely wide [35(1)], ventrally directed tabular in occipital view [48(1)], foramen magnum ventrally constricted [51(1)], presence of the crista falciformis of the squamosal in occipital view [53(1)], deep postemporal fenestra [54(1)], posterior end of the mandible situated behind the quadrate condyle [57(1)], and extended dentary symphysis [60(1)].

The taxon Syrtosuchus samarensis (Novikov 2016) is here found as the most basal taxon of the analyzed taxa. Novikov (2016) erected this taxon and considered it "as the most primitive benthosuchid taxon assigned to a separate benthosuchid subfamily, Syrtosuchinae(...)" (Novikov 2016: p. 307). In the present analysis this taxon represents a stem trematosauroid, and potentially a stem capitosauroid. Future analyses focusing on basal trematosauroids and related taxa should clarify the position of this basal taxon and assess its phylogenetic position.

Lonchorhynchinae is composed by the same taxa (and equal positions) found by Fortuny et al. (2018), while Trematosaurinae is composed by the same taxa as in Fortuny et al. (2018), with the addition of Prothoosuchus blomi (not included in previous analyses). Trematolestes hagdorni is found as the most basal trematosaurine, representing the sister taxon of Thoosuchus yakovlevi. In turn, this latter taxon is the sister taxon of the clade formed by all three Angusaurus species analyzed as well as Prothoosuchus blomi, resulting in a polytomy between these four taxa (node 7, Fig. 4). It should be mentioned that a heuristic analysis (under the same variables) but not including Angusaurus succedaneus resulted in only one Most Parsimonious Tree (MPT) with the same topology as above but with Angusaurus dentatus recovered as the sister taxon of the clade composed by Angusaurus tsylmensis and Prothoosuchus blomi (Fig. 4). In a similar way, the analysis grouping all three Angusaurus species (labeled as Angusaurus spp.) resulted in only one MPT with the same general topology but recovering a clade formed by Angusaurus spp. and Prothoosuchus blomi.

Regarding the rest of trematosaurines, this latter analysis recovered a clade (node 6) composed by Trematosaurus brauni and Trematosuchus sobeyi, not recovered in previous analyses by Fortuny et al. (2018) but present in analyses made by Steyer (2002). Finally, Inflectosaurus and Microposaurus appear as derived trematosaurines (Damiani 2004; Novikov 2007; Warren 2012; Fortuny et al. 2018) and closely related to Platystega, Lyrocephaliscus and Tertrema.

\section{Discussion}

\subsection{Taxonomic and ontogenetic assessment of SMNS 81782}

Trematosauroids are characterized by the formation of the anterior portion of a long and narrow cultriform process from the posterior projections of the vomer (Schoch and Milner, 2000), a feature also found in thoosuchids and in the studied specimen. In the specimen described neither the frontal nor the lacrimal bones have any contact with the orbits, a derived feature also present in Thoosuchus and other trematosauroids (Damiani and Yates 2003). In capitosauroids the lacrimal does not contact the orbits but the frontal maintains its orbit contact, causing a wide separation between the prefrontal and the postorbital, like in Edingerella (Schoch and Milner 2000; Maganuco et al. 2009).

In the trematosaurines Thoosuchus and Angusaurus, as well as SMNS 81782, the supraorbital sulcus runs anteriorly through the nasal, between the nares, and then enters the 
lacrimal, whereas in most capitosauroids this sulcus runs along almost the entire nasal and enters the lacrimal posteriorly (Fig. 1; Damiani and Yates 2003; Maganuco et al. 2009; Schoch and Milner 2000). The presence of the occipital canal is typical of many trematosaurs like Thoosuchus and Angusaurus, while its absence is characteristic of capitosauroids, like Edingerella (Maganuco et al. 2009).

Small trematosaurids exclusively known from the Lower Triassic of the Eastern European Platform are usually referred to Thoosuchidae. This group is characterized by a narrow skull with concave lateral margins and a longer snout than in other trematosauroids, and by the lateral margin of the skull being straight or slightly convex like in Benthosuchus (Schoch and Milner 2000; Novikov 2012a). All these features are also true for the specimen studied herein.

The flexura lacrimalis is represented by a Z-shaped flexura on the lacrimal of the infraorbital sulcus. This flexura is present in thoosuchids, such as Thoosuchus and Angusaurus, as well as in the specimen described, being softer and less sharp in the latter than in other trematosauroids like Benthosuchus (Getmanov 1989; Schoch and Milner 2000; Damiani and Yates 2003; Novikov 2012a).

The jugals of thoosuchids are thinner in comparison with other trematosauroids. These features can be also shared with primitive trematosauroids. In adult benthosuchids, the jugal can have the width of its orbits (Schoch and Milner 2000). The palatine of thoosuchids, as well as the specimen analyzed here, has no posterior process or contact with its pterygoid, whereas the palatines of Benthosuchus connects with the pterygoid (Novikov 2012a; Schoch and Milner 2000).

Taking into account all these features and the fact that the specimen SMNS 81782 cannot be referred to Benthosuchidae-because members of this family have a bilobed anterior palatal vacuity - , nor to Plastystegididae - because its members have a very broad postorbital skull-this specimen is assigned with confidence to Thoosuchidae (sensu Schoch and Milner 2000). Regarding Thoosuchus, the specimen cannot be referred to this genus based on orbit size (bigger in Thoosuchus) as well as the elongation of the postorbital and postfrontal in the studied specimen relative to Thoosuchus. The genus Angusaurus (Figs. 5, 6, 7), as previously mentioned, is characterized by posteriorly elongated postorbitals and postfrontals (Schoch and Milner 2000), as in the studied specimen. The main part of the body of the jugal of the studied specimen is situated in a posterior position, behind the orbits, (Getmanov 1989). The body of the parasphenoid of Angusaurus is slightly longer (Getmanov 1989) than in the studied specimen (Figs. 1, 2, 3, 6). As in SMNS 81782, the pineal foramen of the genus Angusaurus is situated at half the distance between the orbits and the occipital, in a middle position on the parietals (Getmanov 1989). All these characters allow us to assign the studied specimen to the genus Angusaurus.

To date, four Angusaurus species have been erected: A. dentatus, A. succedaneus, A. weidenbaumi and A. tsylmensis (Figs. 5, 6, 7). Unfortunately the diagnostic characters for each one of these species are tenuous. In addition, some of the specimens used in published descriptions are differently preserved in the homologous regions, which precludes in some cases anatomical comparison. A. dentatus (type species of the genus) and A. tsylmensis are erected based on almost complete skulls (but missing some parts of the pterygoids and parasphenoid in A. denta$t u s$, as well as any mandible remain known for this taxon) (Figs. 5, 6, 7) whereas A. weidenbaumi is only known by a snout (not presenting the typical flexura lacrimalis sulcus found in the rest of Angusaurus taxa) and A. succedaneus by a partial skull with well-preserved palate and mandible but missing most of the skull roof and occiput, but associated with a well preserved mandible (Figs. 5, 6, 7).

Hence, the key anatomical characters in the analyzed specimen are: (1) (character 36; see supplementary material) posterior branch of the pterygoid, narrow and elongate (A. dentatus) or short and wide (A. tsylmensis and SMNS 81782); (2) presence of flexura lacrimalis (A. dentatus, A. succedaneus, A. tsylmensis and SMNS 81782) or absence (A. weidenbaumi); (3) the anterior and lateral border of the basal plate of the parashphenoid are almost straight (A. dentatus) or concave (A. succedaneus, A. tsylmensis and SMNS 81782); (4) ventral surface of the parasphenoid plate smoothed (A. dentatus and SMNS 81782) or dot-shaped (A. succedaneus, A. tsylmensis); (5) postemporal fenestra high (the fenestra itself, not its position) ( $A$. dentatus and SMNS 81782) or low (A. tsylmensis).

Nonetheless, the last two characters should be taken with caution: the ornamentation is known to vary with ontogeny (Steyer 2000), and the height difference of the fenestra is not really pronounced and cannot be excluded for preservation reasons (compression).

Overall, all these characters suggest affinities of the studied specimen with A. tsylmensis or A. succedaneus, and prevent the assignment of the former to A. dentatus and $A$. weidenbaumi. However, an attribution to A. succedaneus is not possible to conclude due to the poor state of preservation of some diagnostic characters and anatomical areas (e.g. quadrate ramus) in the holotype (and unique published specimen) of A. succedaneus, and it cannot be discarded that some shared characters with this taxon may be due to ontogeny. Thus, based on the shared characters discussed, SMNS 81782 is referred to as A.cf. tsylmensis. The lack of information on the stratigraphy of the studied 

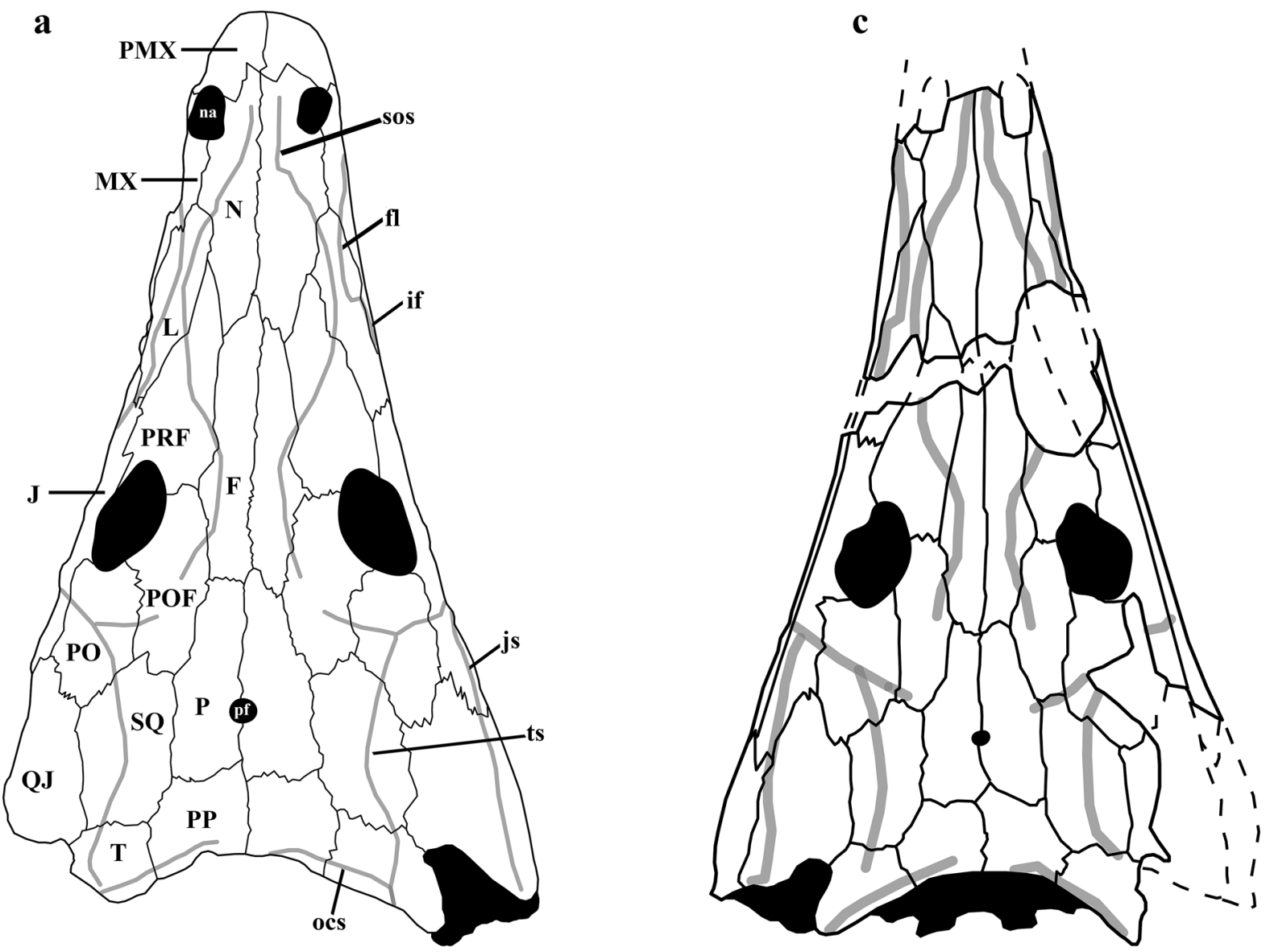

b

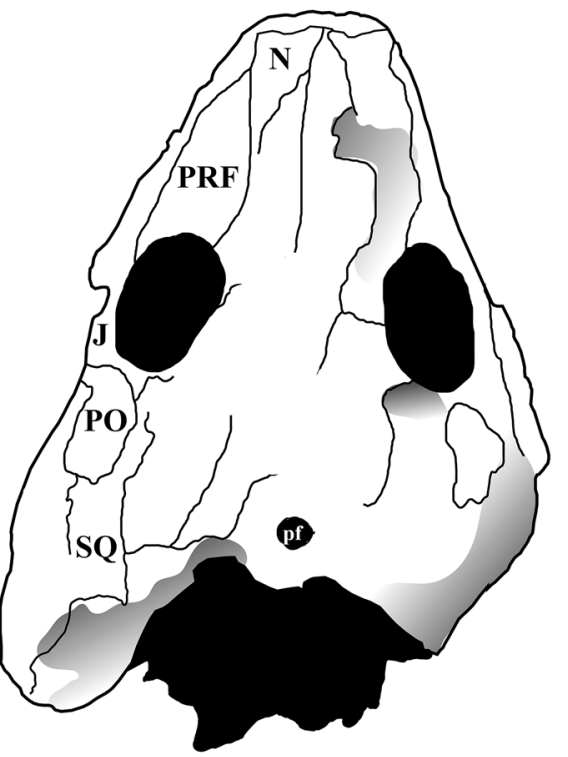

$1 \mathrm{~cm} d$

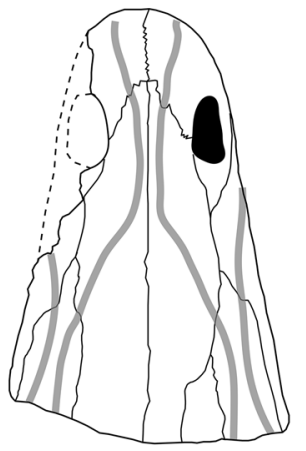

Fig. 5 The genus Angusaurus from the Early Olenekian (Lower Triassic) of Russia. Dorsal view of: A. dentatus (a), A. succedaneus (b), A. tsylmensis (c), A. weidenbaumi (d). Redrawn after Getmanov

1989, Novikov 1990 and personal observations (J.F.). Note that lines for cranial sutures in A. succedaneus are tentative 
Fig. 6 The genus Angusaurus from the Early Olenekian (Lower Triassic) of Russia. Ventral view of: A. dentatus (a), A. succedaneus (b), A. tsylmensis $(\mathbf{c})$ and $A$. weidenbaumi $(\mathbf{d})$. Redrawn after Getmanov 1989, Novikov 1990 and personal observations (J.F.)
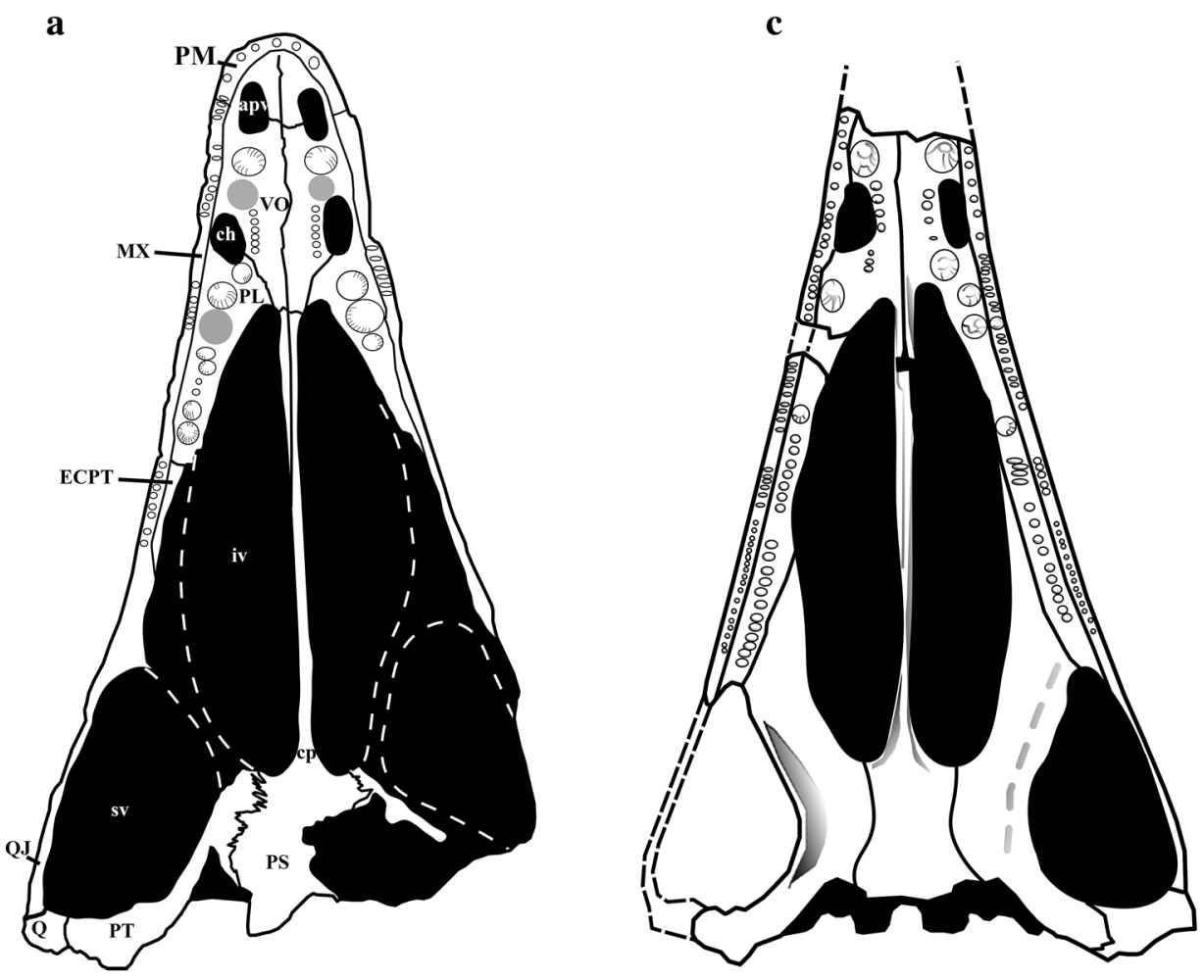

b

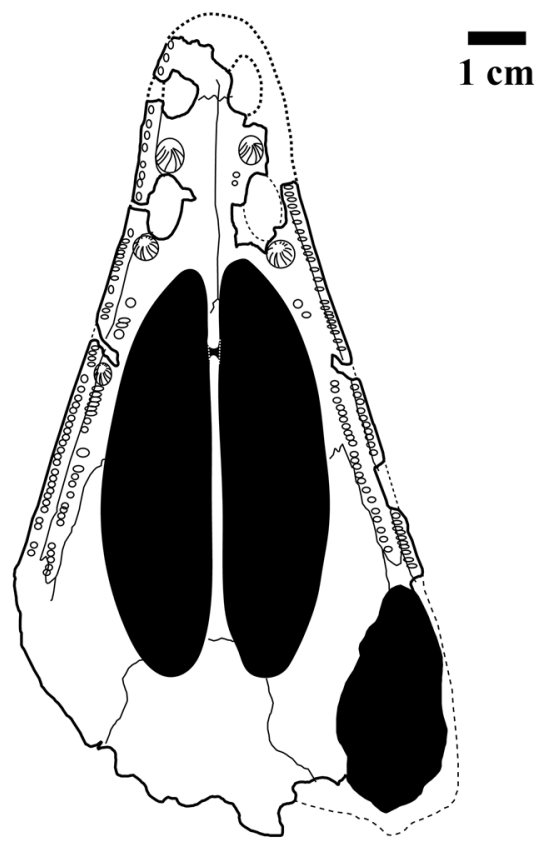

d

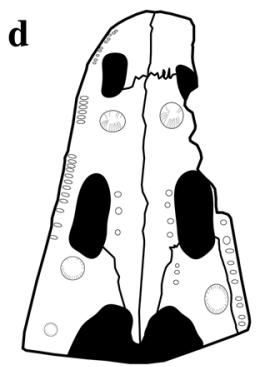

specimen, as well as potential interspecific, intraspecific, ontogenetic or preservation variability preclude a confident assignment to A. tsylmensis.

As previously mentioned, the approximate length of the adult skull for Angusaurus is about $200 \mathrm{~mm}$ (Getmanov 1989), while the studied skull has a length of $112.3 \mathrm{~mm}$, indicating a possible juvenile condition. The radial sculpture of the dermal bones is typically found in growing bones and it can thus be a larval or juvenile character, although this ornamentation can also be found in some adult stereospondyls. Polygonal sculpture comes from the radial sculpture pattern (Witzmann et al. 2010), and SMNS 81782 has mainly polygonal ornamentation in the ossification centre of the skull roof. Although we 
Fig. 7 The genus Angusaurus from the Early Olenekian (Lower Triassic) of Russia. Occipital view of: A. dentatus (a), A. succedaneus (b), A. tsylmensis (c) and mandible in labial (d) and lingual (e) side of A. succedaneus. Redrawn after Getmanov 1989, Novikov 1990 and personal observations (J.F.) $\mathbf{a}$
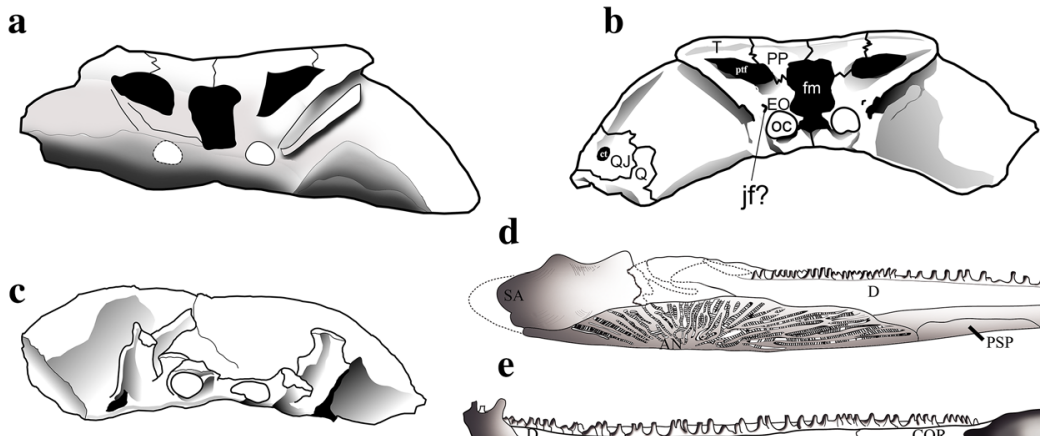
$1 \mathrm{~cm}$ d

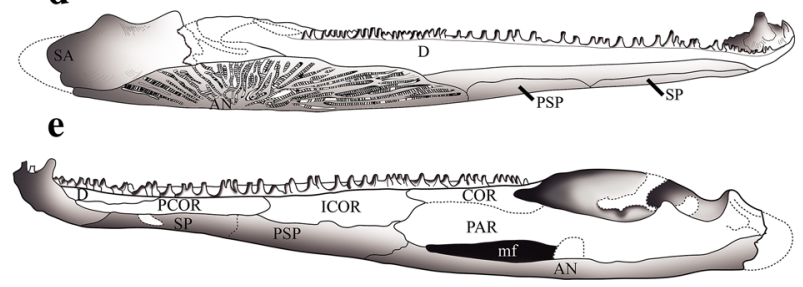

interpret SMNS 81782 as a sub-adult, we cannot reject that this specimen could be an adult considering that the radial pattern can also be present in adults. Sometimes the degree of ossification and the sutural fusion is indicative of a developmental age but in temnospondyls it might not be a significant indicator (Steyer 2000).

\subsection{Angusaurus: taxonomic and phylogenetic considerations}

As previously mentioned, four Angusaurus species have been erected to date (A. dentatus, A. succedaneus, A. weidenbaumi and A. tsylmensis) (Figs. 5, 6, 7). This genus is apparently uniform, with few diagnostic characters allowing differentiation between species. This fact raises the question of the validity of these species. When three species ( $A$. dentatus, A. succedaneus, and A. tsylmensis) are included separately in the phylogenetic analysis, it results in a polytomy (Fig. 4). In particular, two of these species (A. dentatus and A. succedaneus) are virtually equal under the character matrix (depending on the missing data), and it should be considered that both species were recovered from the same subhorizon.

Previously, Schoch and Milner (2000) also questioned the validity of $A$. succedaneus, suggesting it as potential junior synonym of $A$. dentatus. Nonetheless, these authors maintained the validity of these species.

The main reason why we do the same here is because of the difficulty to directly compare A. dentatus, A. succedaneus, and A. weidenbaumi (see above). Although these three taxa are recovered from the same subhorizon (see below), there is a lack of homologous regions preserved in these three species. However, we cannot discard the possibility that future findings may potentially reveal that only one or two of these species are valid, thus raising the possibility of evaluating the intraspecific variability of the genus Angusaurus.

On the other hand, A. tsylmensis is considered more confidently as a valid species because it was recovered from a different (younger) subhorizon (Ust-Mylian) and presents the morphological characters previously discussed (e.g. short and wide posterior branch of the pterygoid; the more anterior position of the quadrate condyle, etc.) (Figs. 5, 6, 7).

\subsection{Biostratigraphy and paleobiogeography of basal trematosauroids, trematosaurids and trematosaurines}

Most trematosaurines have been recovered from the Russian European platform, with the exception of some taxa (e.g. Trematolestes hagdorni, Trematosaurus brauni, Trematosuchus sobeyi etc.) from Central Europe, Spitsbergen, South Africa, Madagascar, North America and Australia. Regarding the communities of Eastern Europe, three different main regions (or realms) can be recognized: (a) the central and northern regions of the East European Platform (Moscow-Mezen, and presumably Pechora, Synclines), and the Timan-North Ural Region; (b) the southern CisUrals, including the Obshchii Syrt Plateau; and (c) the southern regions of the East European Platform (the slope of the Voronezh Anticline) (Shishkin et al. 2006).

From a chronological point of view, these main regions span much of the Lower and Middle Triassic (from the Induan to the Ladinian), with a succession up to $3.5 \mathrm{~km}$ and subdivided in different superhorizons (or gorizonts, here used as synonyms but see Tverdokhlebov et al. 2002 for discussion): Vetlugian superhorizon (Induan-Olenekian), Yarenskian horizon (Olenekian), Donguz horizon (Anisian) and Bukobay horizon (Ladinian). Up to seven faunal assemblages (or svitas, here used as synonyms but see Tverdokhlebov et al. 2002 for discussion) have been proposed for these superhorizons and horizons: Kopanskaya (Induan), Staritskaya, Kzylsaiskaya, Gostevskaya, and Petropavlovskaya (all Olenekian), Donguz (Anisian), and Bukobay (Ladinian) (see Ochev and Shishkin 2000; Tverdokhlebov et al. 2002: fig. 2; Shishkin et al. 2006 for comprehensive reviews, correlation between horizon and assemblages, as well as additional references). 
Herein, we focus on basal trematosauroids, trematosaurids and trematosaurines recovered from the Vetlugian superhorizon and associated with the Benthosuchus-Wetlugasaurus tetrapod complexes. This superhorizon spans the following subhorizons (or gorizonts), from base to top: Vokhmian, Rybinskian, Sludkinskian and Ust-Mylian (Ochev and Shishkin 2000: fig. 1 for a discussion). Vetlugian superhorizon is dated as Olenekian with the exception of the Vokhmian subhorizon (Induan). This latter subhorizon is of particular interest for trematosauroids, since different taxa (as part of the Kopanskaya faunal assemblage) have been recovered from this subhorizon and particularly from the main region of the southern CisUrals and the Obshchii Syrt Plateau. Remarkably, Syrtosuchus and primitive Benthosuchus taxa (e.g. B. gusevae) have also been recovered, as well as other temnospondyls such as Tupilakosaurus and Wetlugasaurus samariensis (Tverdokhlebov et al. 2002; Novikov 2012a, 2016).

Nonetheless, a recent proposed new horizon, Zaplavnenskian Horizon, has been proposed. Its faunal assemblage is still controversial but suggests a late developmental stage of the Tupilakosaurus fauna (see Shishkin and Novikov 2017 and references therein).

The Rybinskian Gorizont (Staristskaya faunal assemblage) is mainly composed of fluvial sandstones, with the usual features of arid zones (Tverdokhlebov et al. 2002). Benthosuchus sushkini and the genus Thoosuchus are the most characteristic taxa for this gorizont, forming a Benthosuchus-Thoosuchus group, typical of this subhorizon but also including other temnospondyl members as Wetlugasaurus, Trematotegmen otschevi and Qantas samarensis (Shishkin et al. 2000; Tverdokhlebov et al. 2002; Novikov 2012b). The Sludkinskian subhorizon (Kzylsaiskaya faunal assemblage) is very similar to the previous one, but in the uppermost part of the section the fluvial deposits are sometimes replaced by deltaic sediments. The fauna is similar to the Rybinskian subhorizon, particularly on the lowermost part of the section. In this faunal assemblage Wetlugasaurus angustifrons is the most common tetrapod, but it also contains other temnospondyls like Wetlugasaurus kzilsajensis, Benthosuchus bashkiricus, Thoosuchus tuberculatus, Angusaurus dentatus, Angusaurus succedaneus, Angusaurus weidenbaumi, Prothoosuchus blomi, and Prothoosuchus samariensis, and the first appearance of the capitosaur genus Parotosuchus (Shishkin et al. 2000; Tverdokhlebov et al. 2002).

Finally, the Ust-Mylian subhorizon (Gostevskaya faunal assemblage and equivalent to the assemblage III of Novikov 1994) constitutes a complex of lacustrine-deltaic accumulations where the most characteristic temnospondyl fauna is composed of Wetlugasaurus malachovi as well as Angusaurus tsylmensis and Vyborososaurus mirus. It also represents the first appearance of the genus Trematosaurus as well as the capitosaur Vladlenosaurus alexeyevi and indeterminate plagisaurids (Ochev and Shishkin 2000; Tverdokhlebov et al. 2002; Shishkin et al. 2006). It should be remarked that this faunal assemblage is the most poorly known due to difficulties recognizing this fauna outside of the northeastern areas of the Russian platform.

Later, the temnospondyl fauna was replaced by the Parotosuchus group, which dominated the Yarenskian subhorizon (Tverdokhlebov et al. 2002).

Taking into account these previous considerations, the Early Olenekian time is of particular interest to understand the origin and diversification of basal trematosaurines. This time is characterized by a eustatic maximum (Lozovsky 1992), which resulted in the expansion of lakes in Eastern Europe (Shishkin et al. 2006) and represented by two subhorizons corresponding to the Early Olenekian: the Sludkinskian (early Early Olenekian) and the Ust-Mylian (late Early Olenekian) (Ochev and Shishkin 2000; Tverdokhlebov et al. 2002). The chronological origin of trematosauroids, trematosaurids and trematosaurines is debated, since the earliest fossil evidence for these groups ranges from (?Late) Induan to Early Olenekian, known from different continents. On the one hand, basal trematosauroids such as Syrthosuchus sp. and Benthosuchus gusevae are recorded from the (?Late) Induan (Vokhmian subhorizon) from the Southern CisUral area-Obshchii Syrt Plateau (Novikov 2012a, 2016). Nonetheless, the poorly known genus Tirraturhinus from the Arcadia Formation (central Queensland, Australia) has been dated as (Early) Induan and proposed as a trematosaurine (Nield et al. 2006; Warren et al. 2006; but see discussion about alternative dating and taxonomic position in Shishkin et al. (2006) and Novikov (2012b).

On the other hand, recent phylogenetic analyses place the genus Trematolestes as the most basal trematosaurine (Fortuny et al. 2018, present study), but also resembling in some characters lonchorhynchines (Schoch 2006). This wellknown taxon is recorded from the Middle Triassic (Lower Keuper facies, Upper Ladinian) of Germany and is closely related to the Early Triassic Malagasy genus Tertremoides (Schoch 2006). If this is correct, Tertremoides, recovered from the NW of Madagascar (Ankitokazo basin, Sakamena Group, Ambilobe region), has to be considered a basal trematosaurine. This genus is found in similar levels among other trematosaurids such as Wantzosaurus and Aphaneramma (Steyer 2002; Fortuny et al. 2018). The Ankitokazo basin was originally dated as Induan (Scythian A1), but later redated as Olenekian based on conchostracans (Yanbin et al. 2002).

Overall, the first trematosauroid datum implies an open paleobiogeographical scenario where basal trematosauroids may have originated during the Induan at the Cis-UralianObshchii Syrt Plateau region of the Eastern Europe platform (Novikov 2016), but without excluding the possibility of an Australian (Nield et al. 2006) or East Greenland (see 
below) trematosauroid origin and/or even suggesting paleobiogeographical link between East Greenland, Cis-UralianObshchii Syrt Plateau (Russia) and Queensland (Australia). Otherwise, the trematosauroid split between short-snouted forms (e.g. trematosaurines) and long snouted ones (lonchorhynchines), is particularly unclear based on the presence of the most basal members of these groups during the Late Induan- (?Early) Olenekian in different continents: East Greenland (Stoschiosaurus, Late Induan, Nielsen 1935; Zaton et al. 2016); Eastern Europe (ThoosuchusEarly Olenekian, Ochev and Shishkin 2000) and Madagascar (Tertremoides-Olenekian unprecise age, Maganuco and Pasini 2009; Wantzosaurus-Olenekian unprecise age, Steyer 2002). Taking into account these data, we come up with, at least, two hypotheses: (A) the first appearance of basal trematosauroids and trematosaurids is older than current fossil record evidence suggests; (B) supposed basal lonchorhynchines and trematosaurines (as Stoschiosaurus or Tertremoides) may be basal trematosauroids instead of lonchorhynchines or trematosaurines, and consequently a taxonomical re-assignment and definition of these groups is required (provided that new material is found).

Lastly, the trematosaurine radiation that started in Eastern Europe with the appearance of Thoosuchus and subsequent related genera such as Angusaurus, Prothoosuchus and Vyborosaurus during the Early Olenekian potentially expanded to Central European basins (with paleobiogeographical connection between the southern regions of the East European Platform, Shishkin et al. 2006) represented by the presence of the genus Trematosaurus in both areas (Schoch and Milner 2000; Novikov 2010). The Trematosaurus radiation during the Late Olenekian also derived in the presence of advanced trematosaurines such as Inflectosaurus, Platystega, Tertrema and Lyrocephaliscus in the Eastern European platform and Spitsbergen (Svalbard), and also in southern latitudes such as South Africa (Karoo basin) during the Late Olenekian-Early Anisian, represented by Trematosuchus and Microposaurus (Schoch and Milner 2000).

\section{Conclusions}

The genus Angusaurus, present from the early Early Olenkian to late Early Olenekian in Russia, is a trematosaurine characterized by skulls about $200 \mathrm{~mm}$ long (adult size), small orbits (compared to the close genus Thoosuchus), elongated postorbitals and postfrontals, with a very reduced interchoanal tooth row and a ventral opening of the orbits in the middle part of the skull, presenting a mandible with an elongate postglenoid process (PGA) and well developed suprangular. The new specimen described herein sheds some light on the ontogeny of this genus, with implications for other trematosaurines. The genus Angusaurus includes four species with few key anatomical characters. While the type species, Angusaurus dentatus, and Angusaurus tsylmensis are well supported, the validity of Angusaurus succedaneus and Angusaurus weidenbaumi is controversial and new findings are required to fully evaluate their validity and better understand the intraspecific variability of this genus. Deciphering the evolution of trematosaurines during the Early Olenekian is key to understanding the origin and diversification of basal trematosaurines with implications to clarify the different paleobiogeographical scenarios that remain still open.

Acknowledgements Our special thanks to Dr. Rainer Schoch (SMNS, Stuttgart) for the access and loan of the studied specimen and to Dr. Igor V. Novikov (PIN, Moscow) for providing photos and relevant data about Russian trematosaurids. Sergio Llacer is acknowledged for his help during segmentation process of the studied specimen and Montse Vilalta for assistance in some drawings. Judit Marigó proofread the paper and revised English grammar. J. Fortuny acknowledges the support of the postdoc Grant Agència de Gestió d'Ajuts Universitaris i de Recerca, "Beatriu de Pinós" 2014-BP-A 00048 from the Generalitat de Catalunya. This work received support from CERCA programme (Generalitat de Catalunya).

\section{References}

Arbez, T., Dahoumane, A., \& Steyer, J. S. (2017). Exceptional endocranium and middle ear of Stanocephalosaurus (Temnospondyli: Capitosauria) from the Triassic of Algeria revealed by micro-CT scan, with new functional interpretations of the hearing system. Zoological Journal of the Linnean Society, 180(4), 910-929.

Bystrow, A. P., \& Efremov, J. A. (1940). Benthosuchus sushkini: A labyrinthodont from the Eotriassic of Sharzhenga River. Trudy Paleozoologicheskogo Instituta Akademii Nauk SSSR, 10, 1-152.

Damiani, R. J. (2004). Cranial anatomy and relationships of Microposaurus casei, a temnospondyl from the Middle Triassic of South Africa. Journal of Vertebrate Paleontology, 24, 533-541.

Damiani, R. J., \& Yates, A. M. (2003). The Triassic amphibian Thoosuchus yakovlevi and the relationships of the Trematosauroidea (Temnospondyli: Stereospondyli). Records of the Australian Museum, 55, 331-342.

Fortuny, J., Gastou, S., Escuillié, F., Ranivoharimanana, L., \& Steyer, J. S. (2018). A new extreme longirostrine temnospondyl from the Triassic of Madagascar: Phylogenetic and palaeobiogeographical implications for trematosaurids. Journal of Systematic Palaeontology, 16(8), 675-688.

Fortuny, J., Marcé-Nogué, J., Steyer, J.-S., De Esteban-Trivigno, S., Mujal, E., \& Gil, Ll. (2016). Comparative 3D analyses and palaeoecology of giant early amphibians (Temnospondyli: Stereospondyli). Scientific Reports, 6, 30387.

Getmanov, S. N. (1982). A labyrinthodont from the Lower Triassic of the Obshchiy Syrt region. Paleontological Journal, 16, 102-106.

Getmanov, S. N. (1989). Triassic amphibians of the East European platform (family Benthosuchidae Efremov). Trudy Paleontol Instituta, 236, 1-102. [In Russian].

Grauvogel-Stamm, L., \& Ash, S. R. (2005). Recovery of the Triassic land flora from the end-Permian life crisis. Comptes Rendus Palevol, 4, 593-608. 
Hellrung, H. (1987). Revision von Hyperokynodon keuperinus Plieninger (Amphibia: Temnospondyli) aus dem Schilfsandstein von Heilbronn (Baden-WuÈrttemberg). Stuttgarter Beiträge zur Naturkunde, 136, 1-28.

Kathe, W. (1999). Comparative morphology and functional interpretation of the sutures in the dermal skull roof of temnospondyl amphibians. Zoological journal of the Linnean Society, 126, 1-39.

Kuzmin, T. M. (1935). Lower Triassic Stegocephalia from the northern part of the Oka-Tsna ridge. Trematosaurus weidenbaumi nov. sp. Annales de la Societe Paleontologie de Russie, 10, 39-48.

Lozovsky, V.R. (1992). The Early Triassic Stage in the development of Western Laurasia. Extended Abstract of Doctoral Dissertation in Geology and Mineralogy. Moscow: Geology Razprave Institute, Moscow.

Maganuco, S., \& Pasini, G. (2009). A new specimen of trematosaurian temnospondyl from the Lower Triassic of NW Madagascar, with remarks on palatal anatomy and taxonomic affinities. Atti della Società italiana di scienze naturali e del Museo cívico di storia naturale di Milano, 150(1), 91-112.

Maganuco, S., Steyer, J. S., Pasini, G., Boulay, M., Lorrain, S., Bénéteau, A., et al. (2009). An exquisite specimen of Edingerella madagascariensis (Temnospondyli) from the Lower Triassic of NW Madagascar; cranial anatomy, phylogeny, and restorations. Memorie della Società Italiana di Scienze Naturali e del Museo Civico di Storia Naturale di Milano, 36, 1-71.

Mazin, J. M., \& Janvier, P. (1983). L'anatomie de Lyrocephaliscus euri (Wiman), trématosaure du Trias Inférieur du Spitsberg: Arrièrecrane, squelette axial et ceinture scapulaire. Palaeovertebrata, 13, $13-31$.

Milner, A. R. (1990). The radiations of temnospondyl amphibians. The Systematics Association, 42, 321-349.

Nield, C., Damiani, R., \& Warren, A. (2006). A short-snouted trematosauroid (Tetrapoda, Temnospondyli) from the Early Triassic of Australia: The oldest known trematosaurine. Alcheringa, 30(2), 263-271.

Nielsen, E. (1935). The Permian and Eotriassic vertebrate-bearing beds at Godthaab Gulf (East Greenland). Meddelelser om Grønland, 98, 1-109.

Novikov, I. V. (1990). New Early Triassic labyrinthodonts of the Middle ForeUrals. Paleontological Journal, 1, 86-100.

Novikov, I. V. (1994). Biostratigrafiya kontinental'nogo triasa TimanoSeveroural'skogo regiona po faune tetrapod (Biostratigraphy of Continental Triassic Timan-North Ural Region Based on the Tetrapod Fauna). Moscow: Nauka Press.

Novikov, I. V. (2007). New data on trematosauroid labyrinthodonts of Eastern Europe: 1. Genus Inflectosaurus Shishkin, 1960. Paleontological Journal, 41, 167-174.

Novikov, I. V. (2010). New data on Trematosauroid Labyrinthodonts of Eastern Europe: 2. Trematosaurus galae sp. nov.: Cranial Morphology. Paleontological Journal, 44, 457-467.

Novikov, I. V. (2012a). New data on trematosauroid labyrinthodonts of Eastern Europe: 4. Genus Benthosuchus Efremov, 1937. Paleontological Journal, 46(4), 400-411.

Novikov, I. V. (2012b). New data on trematosauroid labyrinthodonts of Eastern Europe: 3. Qantas samarensis gen. et sp. nov. Paleontological Journal, 42(2), 177-186.

Novikov, I. V. (2016). New temnospondyl amphibians from the Lower Triassic of Obshchy Syrt (Eastern Europe). Paleontological Journal, 50(3), 297-310.

Ochev, V. G., \& Shishkin, M. A. (2000). Hierarchy of Lower Triassic stratigraphic units in the eastern part of European Russia. Doklady Earth Sciences, 374(7), 1103-1106.

Säve-Söderbergh, G. (1936). On the morphology of Triassic stegocephalians from Spitsbergen, and the interpretation of the endocranium in the Labyrinthodontia. Kunglik Svensk Vetenskapsakademiens Handlingar, 16, 1-181.
Schoch, R. R. (1999). Comparative osteology of Mastodonsaurus giganteus (Jaeger, 1828) from the Middle Triassic (Lettenkeuper: Longobardian) of Germany (Baden-Württemberg, Bayern, Thüringen). Stuttgarter Beiträge zur Naturkunde B, 278, 1-175.

Schoch, R. R. (2006). A complete trematosaurid amphibian from the Middle Triassic of Germany. Journal of Vertebrate Paleontology, 26, 29-43.

Schoch, R. R. (2013). The evolution of major temnospondyl clades: An inclusive phylogenetic analysis. Journal of Systematic Palaeontology, 11(6), 673-705.

Schoch, R.R. \& Milner, A.R. (2000). Stereospondyli. Handbuch der Paläoherpetologie, Teil 3B. München: Verlag Dr. Friedrich Pfeil.

Sennikov, A. G. (1996). Evolution of the Permian and Triassic tetrapod communities of Eastern Europe. Palaeogeography, Palaeoclimatology, Palaeoecology, 120, 331-351.

Shishkin, M. A., \& Novikov, I. V. (2017). Early stages of recovery of the East European tetrapod fauna after the End-Permian crisis. Paleontological Journal, 51(6), 612-622.

Shishkin, M. A., Ochev, V. G., Lozovskii, V. R., \& Novikov, I. V. (2000). Tetrapod biostratigraphy of the Triassic of Eastern Europe. In M. J. Benton, M. A. Shishkin, D. M. Unwin, \& D. M. Kurochkin (Eds.), The Age of Dinosaurs in Russia and Mongolia (pp. 120-139). Cambridge: Cambridge Univerdity press.

Shishkin, M., Sennikov, A. G., Novikov, I. V., \& Ilyna, N. V. (2006). Differentiation of tetrapod communities and some aspects of biotic events in the Early Triassic of Eastern Europe. Paleontological Journal, 40(1), 1-10.

Stayton, C. T., \& Ruta, M. (2006). Geometric morphometrics of the skull roof of stereospondyls (Amphibia: Temnospondyli). Palaeontology, 49, 307-337.

Steyer, J. S. (2000). Ontogeny and phylogeny in temnospondyls: A new method of analysis. Zoological Journal of the Linnean Society, 130, 449-467.

Steyer, J.-S. (2002). The first articulated trematosaur "amphibian" from the lower Triassic of Madagascar: Implications for the phylogeny of the group. Palaeontology, 45, 771-793.

Tuniz, C., Bernardini, F., Cicuttin, A., Crespo, M. L., Dreossi, D., Gianoncelli, A., et al. (2013). The ICTP-Elettra X-ray laboratory for cultural heritage and archaeology. Nuclear Instruments and Methods in Physics Research, Section A: Accelerators, Spectrometers, Detectors, and Associated Equipment, 711, 106-110.

Swofford, D. L. (2001). PAUP: Phylogenetic Analysis Using Parsimony, Version 4.0b10. Smithsonian Institution, Washington.

Tverdokhlebov, V. P., Tverdokhlebova, G. I., Surkov, M. V., \& Benton, M. J. (2002). Tetrapod localities from the Triassic of the SE of European Russia. Earth-Science Reviews, 60, 1-66.

Warren, A. A. (2012). The South African stereospondyl Microposaurus from the Middle Triassic of the Sydney Basin, Australia. Journal of Vertebrate Paleontology, 32(3), 538-544.

Warren, A. A., Damiani, R., \& Yates, A. M. (2006). The South African stereospondyl Lydekkerina huxleyi (Tetrapoda, Temnospondyli) from the Lower Triassic of Australia. Geological Magazine, 143(6), 877-886.

Welles, S. P. (1993). A review of the lonchorhynchine trematosaurs (Labyrinthodontia), and a description of a new genus and species from the Lower Moenkopi Formation of Arizona. PaleoBios, 14, $1-24$.

Witzmann, F., Scholz, H., Müller, J., \& Kardjilov, N. (2010). Sculpture and vascularization of dermal bones, and the implications for the physiology of basal tetrapods. Zoological Journal of the Linnean Society, 160, 302-340.

Yanbin, S., Garassino, A., \& Teruzzi, G. (2002). Studies on PermoTrias of Madagascar. 4. Early Triassic conchostracans from Madagascar. Atti e della Società Italiana di Scienze Naturali e del Museo Civico Di Storia Naturale in Milano, 143, 3-11. 
Yates, A. M., \& Warren, A. A. (2000). The phylogeny of the 'higher' temnospondyls (Vertebrata: Choanata) and its implications for the monophyly and origins of the Stereospondyli. Zoological Journal of the Linnean Society, 128, 77-121.
Zaton, M., Niedzwiedzki, G., Blom, H., \& Kear, B. P. (2016). Boreal earliest Triassic biotas elucidate globally depauperate hard substrate communities after the end-Permian mass extinction. Scientific Reports, 6, 36345.

\section{Affiliations}

\section{Meritxell Fernández-Coll ${ }^{1}$ Thomas Arbez ${ }^{2} \cdot$ Federico Bernardini $^{3,4} \cdot$ Josep Fortuny $^{2,5}$}

Josep Fortuny

josep.fortuny@icp.cat

1 Faculty of Life and Environmental Sciences, University of Iceland, Askja, Sturlugata 7, 101 Reykjavík, Iceland

2 Centre de Recherches sur la Paléobiodiversité et les Paléoenvironnements, UMR 7207 CNRS-MNHN-UPMC, Muséum national d'Histoire naturelle, CP38, 8 rue Buffon, 75005 Paris, France
3 Centro Fermi, Museo Storico della Fisica e Centro di Studi e Ricerche, 'Enrico Fermi', Piazza del Viminale 1, 00184 Rome, Italy

4 Multidisciplinary Laboratory, the 'Abdus Salam' International Centre for Theorethical Physics, Via Beirut 31, 34151 Trieste, Italy

5 Institut Català de Paleontologia M. Crusafont, Clde les Columnes, s/n, Universitat Autònoma de Barcelona, 08193 Cerdanyola del Vallès, Spain 
Table 1. Measuraments of Angusaurus cf. tsylmensis (SMNS 81782). Measuraments in mm.

1 Skull length

2 Skull width

3 Skull height

4 Right orbit length

5 Right orbit width

6 Left orbit length

7 Left orbit width

8 Posterior interorbital distance

9 Interorbital distance

10 Distance from right orbit to the premaxilla

11 Distance from right orbit to the right otic notch

12 Distance from left orbit to the premaxilla

13 Distance from left orbit to the left otic notch

14 Pineal foramen diameter
76.3

112.3 Distance from the premaxilla to the posterior end of the postparietals

74.1 Maximum width of the skull

$28.1 \quad$ Maximum height of the skull

19.1 Maximum length of the right orbit

13.0 Maximum width of the right orbit

17.9 Maximum length of the left orbit

12.3 Maximum width of the left orbit

39.0 Distance between the posterior edge of both orbits

23.3 Distance between the wider part of both orbits

77.2 Distance from the posterior edge of the right orbit to the premaxilla Distance from the posterior edge of the right orbit to the right otic notch

Distance from the posterior edge of the left orbit to the premaxilla

31.8 Distance from the posterior edge of the left orbit to the left otic notch 4.0 Pineal foramen diameter 
15 Distance from Pineal foramen to the end of postparietal

16 Distance from Pineal foramen to the orbits

17 Distance between both Tabular horns

18 Minimum distance between exoccipitals condyles

19 Maximum distance between exoccipitals condyles

20 Parasphenoid length

21 Parasphenoid width

22 Maximum right pterygoid width

23 Maximum left pterygoid width

10.0

24 Right pterygoid width

25 Left pterygoid width
18.1

15.3

19.5

46.3

8.1

16.2

Distance between de distal point outermost of the exoccipitals condyles

Maximum length of the parasphenoid bone

Maximum width of the parasphenoid bone

8.8 Distance between the parasphenoid bone and the right supratemporal vacuity

Distance between the parasphenoid bone and the left supratemporal vacuity

Right pterygoid width between right supratemporal vacuity and right interpterygoid vacuity

8.0 Left pterygoid width between left supratemporal vacuity and left 
interpterygoid vacuity

26 Cultriform process posterior width

27 Cultriform process medial width

28 Cultriform process anterior width

29 Right supratemporal vacuity length

30 Right supratemporal vacuity width

31 Left supratemporal vacuity length

32 Left supratemporal vacuity width

33 Right interpterygoid vacuity length

34 Right interpterygoid vacuity width

35 Left interpterygoid vacuity length

36 Left interpterygoid vacuity width

37 Right choana length

38 Right choana width
13.9

Width of the cultriform process in a posterior position

$0.8 \quad$ Width of the cultriform process in a middle position

6.3 Width of the cultriform process in an anterior position

37.6 Maximum length of the right supratemporal vacuity

19.3 Maximum width of the right supratemporal vacuity

34.6 Maximum length of the left supratemporal vacuity

18.6 Maximum width of the left supratemporal vacuity

63 Maximum length of the right interpterygoid vacuity

16.2 Maximum width of the right interpterygoid vacuity

64.1 Maximum length of the left interpterygoid vacuity

15.3 Maximum width of the left interpterygoid vacuity

11.9 Maximum length of the right choana

4.2 Maximum width of the right choana 
41 Right exoccipital condyle diameter

6.1 Right exoccipital condyle diameter

42 Left exoccipital condyle diameter

5.7 Left exoccipital condyle diameter

43 Total foramen magnum length

14.0 Maximum length of the foramen magnum

44 Maximum foramen magnum width

9.4 Maximum width of the foramen magnum

45 Right postemporal fenestra length

4.2 Total length of the right postemporal fenestra

46 Right postemporal fenestra width

10.1 Total width of the right postemporal fenestra

47 Left postemporal fenestra length

Total length of the left postemporal fenestra

48 Left postemporal fenestra width Total width of the left postemporal fenestra 


\section{Appendix 1}

\section{Character list}

Characters of the skull roof

1. Skull roof elongate (midline length $>$ maximum width; 1 ) or not $(0)$.

2. Position of the centre of the orbit along the dorsal midline of the skull: orbit posteriorly (0) or anteriorly (1) situated.

3. Short (0), constricted (1), or elongated (2) snout (preorbital part of the skull twice longer than the postorbital one; 2 ).

4. Large (0) or small orbit (maximum size $<14$ per cent of the dorsal midline length; 1 ).

5. Orbit facing laterally (1) or dorsally (0).

6. Rounded (0) or oval (1) orbit.

7. Slightly concave (0) or semicircular (1) posterior margin of the skull roof.

8. Nostril rounded (0), ovoid (1), or elongate (2).

9. Nostril in lateral position (1) or not (0).

10. Skull roof bulged (1) or not (0) at the level of the orbits.

11. Pineal foramen small (0) or large (1) relative to the size of the skull roof.

12. Pineal foramen rounded (0) or not (1).

13. Presence (1) or absence (0) of sensory-line grooves in front of the orbits.

14 . Presence (0) or absence (1) of sensory-line grooves behind orbits.

15. Frontal extended behind orbit (1) or not (0).

16. Frontal in contact with orbit (1) or not (0).

17. Presence (1) or absence (0) of the interfrontal.

18. Presence (1) or absence (0) of the centroparietal.

19. Septomaxilla visible (0) or not (1) on the dorsal side of the skull.

20. Otic notch deep and narrow (0), or deep and open (1), or shallow and open (2).

21. Tabular rounded (0), pointed (1), or hook-shaped (2).

22. Quadrate condyle posterior (0) or anterior (1) to the occipital condyle.

23. Presence (1) or absence (0) of an anterodorsal dentary foramen.

24. Premaxilla/nasal suture posteriorly directed (the premaxilla is partly extended posterior to the nostril; 0), straight (1), or anterior directed (2).

25. Presence (1) or absence (0) of a prenarial growth zone.

26. Presence (1) or absence (0) of a 'temporal fossa' (sensu Damiani 1998; a slight depressed region of the skull roof anteriorly to the otic notches).

27. Ventral opening of the orbit at the level of the posterior half (0), in the mid part (1), or in the anterior half (2) of the interpterygoid vacuity.

\section{Characters of the palate}

28. Vomer in contact (1) or not (0) with the maxilla.

29. Choana rounded (0) or elongate (1).

30. Choana overlapping the nostril (1) or not (0).

31 . Absence (0) or presence of a single (1) or of a paired (2) anteropalatal vacuity.

32. Anteropalatal vacuity(ies) posterior (0), between (1), or anterior (2) to the premaxilla/vomerine suture.

33. Interpterygoid vacuity posteriorly (0) or anteriorly (1) widened, or not widened at all (2).

34. Presence (1) or absence (0) of a crista obliqua on the ventral surface of the pterygoid.

35. Anterior branch of the pterygoid laterally extended (0), entirely wide (1), or narrow (2). 
36. Posterior branch ('quadrate ramus') of the pterygoid narrow and elongate (0), or short and wide (1).

37. Presence (0) or absence (1) of an area asparta of the pterygoid.

38. Wide (0), narrow (1) or knife-edged (2) cultriform process of the parasphenoid.

39. Elongate (0) or very short (or absent) (1) suture between the palatine and the pterygoid.

40. Very short (0) or elongate (1) suture between the pterygoid and parasphenoid.

41. Wide (width>length; 0 ) or narrow (length > width; 1 ) parasphenoid plate.

42. Presence (1) or absence (0) of the crista muscularis of the parasphenoid.

43. Carotid canal visible (1) or not (0) on the ventral surface of the parasphenoid.

44. Presence (0) or absence (1) of ectopterygoidal tusks.

45. Suture between the exoccipital and the pterygoid visible (1) or not (0) in ventral view.

Characters of the occiput

46. Presence (1) or absence (0) of the paraquadrate foramen (foramen for the chorda tympani).

47. Flattened (0) or deep (1) occiput, in occipital view.

48. Dorsally (0) or ventrally (1) directed tabular, in occipital view.

49. Small (0) or large (1) occipital condyle.

50 . Occipital condyles widely separated (0) or not (1) from each other.

51 . Foramen magnum ventrally constricted (1) or not (0).

52. Curved (0) or straight (1) dorsal margin of the foramen magnum.

53. Presence (1) or absence (0) of the crista falciformis of the squamosal, in occipital view.

54. Shallow (0) or deep (1) posttemporal fenestra.

55. Elongate (0), triangular (1) or rounded (2) posttemporal fenestra.

56 . Wide (0) or narrow (1) proximal part of the stapes.

Characters of the mandible

57. Posterior end of the mandible situated at the same level (0) or behind (1) the quadrate condyle.

58. Mandible deep (0) or shallow (1) in lateral view.

59. Presence (1) or absence (0) of an anterior constriction of the ventral outline of the mandible, in lateral view.

60 . Reduced (0) or extended (1) dentary symphysis.

61. Presence (1) or absence (0) of a parasymphysial tusk.

62. Presence (0) or absence (1) of a parasymphysial tooth row.

63. Presence (1) or absence (0) of denticles on coronoids 2 and 3.

64 . Presence (1) or absence (0) of sensory-line grooves on the mandible.

65. Meckelian foramen short (0) or elongate (1).

66. Poorly developed or absent (0), or well-developed (1) crista medialis (sensu

Damiani 1998); a vertical blade on the midline of the postglenoid area (PGA sensu Jupp and Warren 1986).

67. Presence (1) or absence (0) of the crista articularis (sensu Damiani 1998); a vertical blade on the postero-lingual border of the PGA.

Characters of the postcranial skeleton

68. Interclavicle narrow (1) or not (0). 
69. Interclavicle with (0) or without (1) dorsal crest(s) (trabeculae sensu Bystrow and Efremov 1940; i.e. relatively wide and flat walls posteriorly and antero-laterally directed on the dorsal surface of the interclavicle). 


\section{Institutional Abbreviations}

NHMUK: The Natural History Museum, London, UK; MGUH: Museum Geologicum

Universitatis Hafniensis, Kobenhavn, Denmark; MNB: Museum für Naturkunde,

Berlin, Germany; MNHN: Muséum national d'Histoire naturelle, Paris, France;

MSNM: Museo di Storia Naturale di Milano, Italy; PIN: Paleontological Institute,

Moscow, Russian Federation; SMNS: Staatliches Museum für Naturkunde in Stuttgart,

Germany; UA: Université d'Antananarivo, Madagascar.

\begin{tabular}{|c|c|c|}
\hline Terminal taxa & Specimens & Literature \\
\hline Angusaurus dentatus & PIN 4196/1 & $\begin{array}{l}\text { Getmanov 1989; Damiani } \\
\text { and Yates, } 2003\end{array}$ \\
\hline Angusaurus succedaneus & & Getmanov, 1989 \\
\hline Angusaurus tsylmensis & PIN 4333/6 & Novikov, 1990 \\
\hline $\begin{array}{l}\text { Aphaneramma } \\
\text { gavialimimus }\end{array}$ & $\begin{array}{l}\text { UA-Amb007, MNHN- } \\
6703\end{array}$ & Fortuny et al. in press \\
\hline Aphaneramma rostratum & $\begin{array}{l}\text { MNHN 20-IBSEN 1969, } \\
\text { MNHN Rotunda 1964, } \\
\text { MNHN St 62, MNHN Tr } \\
\text { A } 64\end{array}$ & $\begin{array}{l}\text { Säve-Söderbergh 1936, } \\
\text { 1937; Welles 1993; } \\
\text { Smith-Woodward 1904; } \\
\text { Wiman } 1916\end{array}$ \\
\hline Aphaneramma kokeni & & Huene 1920; Welles, 1993 \\
\hline Archegosaurus decheni & $\begin{array}{l}\text { MNB Am 114-119, 121- } \\
131,137 \\
\text { MNHN 1868-1-4 1870- } \\
479-480 \text {, } \\
\text { MNHN 1884-10, 21-25; }\end{array}$ & $\begin{array}{l}\text { Gubin 1997; Jaeckel 1896; } \\
\text { Witzmann } 2006\end{array}$ \\
\hline Benthosuchus sushkini & $\begin{array}{l}\text { PIN 2424/4, PIN 2424/10, } \\
\text { PIN 2-19-2252, PIN } \\
2252 / 41\end{array}$ & $\begin{array}{l}\text { Bystrow and Efremov, } \\
1940\end{array}$ \\
\hline Cosgriffius campi & & Welles 1993 \\
\hline $\begin{array}{l}\text { Edingerella } \\
\text { madagascariensis }\end{array}$ & $\begin{array}{l}\text { MNHN MAE3000-3009; } \\
\text { MSNM V2992 }\end{array}$ & $\begin{array}{l}\text { Damiani 1998; Lehman } \\
\text { 1961; Warren 1980; } \\
\text { Maganuco et al. 2009; } \\
\text { Steyer } 2003\end{array}$ \\
\hline Inflectosaurus amplus & & $\begin{array}{l}\text { Jaeckel 1922; Shishkin } \\
\text { 1960; Novikov } 2007\end{array}$ \\
\hline Lyrocephaliscus euri & MNHN F SVT 520 & $\begin{array}{l}\text { Säve-Söderbergh 1935, } \\
\text { 1936, 1937; Mazin and } \\
\text { Janvier 1983 }\end{array}$ \\
\hline Microposaurus casei & & Damiani 2004 \\
\hline Onchiodon frossardi & MNHN 1908-20-26 & $\begin{array}{l}\text { Werneburg and Steyer } \\
1999\end{array}$ \\
\hline
\end{tabular}




\begin{tabular}{|c|c|c|}
\hline Platystega depressa & & $\begin{array}{l}\text { Säve-Söderbergh 1936; } \\
\text { Wiman } 1916\end{array}$ \\
\hline Prothoosuchus blomi & & Getmanov, 1989 \\
\hline Stoschiosaurus nielseni & $\begin{array}{l}\text { MGUH At. } 6,7,9,12,23 \text {, } \\
43,45,46\end{array}$ & Säve-Söderbergh 1935 \\
\hline Syrthosuchus samarensis & & Novikov, 2016 \\
\hline Thoosuchus yakovlevi & SMNS 58880 & $\begin{array}{l}\text { Damiani and Yates, 2003; } \\
\text { Novikov, } 2007\end{array}$ \\
\hline Tertrema acuta & & $\begin{array}{l}\text { Säve-Söderbergh 1936; } \\
\text { Wiman } 1916\end{array}$ \\
\hline Trematolestes hagdorni & $\begin{array}{l}\text { SMNS } 81790-91, \text { SMNS } \\
90022,\end{array}$ & Schoch 2006 \\
\hline Trematosaurus brauni & $\begin{array}{l}\text { BMNH 30270, 36354-75, } \\
40042 \\
\text { MNB Am943 1/3 } \\
\text { MNHN AC9573 }\end{array}$ & $\begin{array}{l}\text { Burmeister 1849; } \\
\text { Drevermann 1920; } \\
\text { Lehman 1966, 1979; }\end{array}$ \\
\hline Trematosuchus sobeyi & & $\begin{array}{l}\text { Haughton 1915; Shishkin } \\
\text { and Welman 1994 }\end{array}$ \\
\hline Wantzosaurus elongatus & MNHN MAE 3030, 3034; & Lehman 1961; Steyer 2002 \\
\hline
\end{tabular}




\section{Apomorphy lists:}

Branch Character Steps CI Change

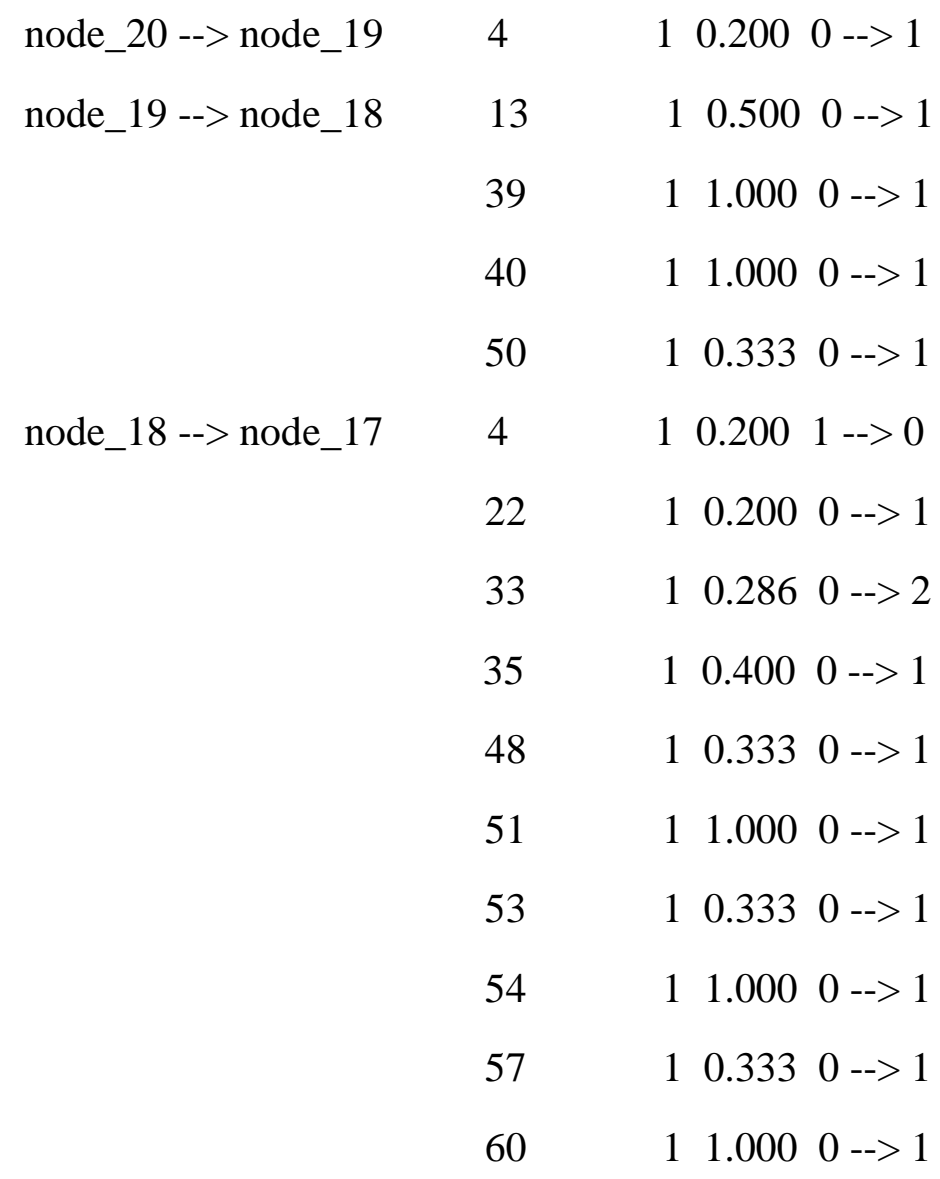

node_17 --> node_16 $\quad 8 \quad \begin{array}{llllll} & 0.250 & 2 & \text {--> } & 1\end{array}$

$\begin{array}{lllll}20 & 1 & 0.333 & 0 & -->\end{array}$

$\begin{array}{lllll}32 & 1 & 0.400 & 0 & -->\end{array}$

$\begin{array}{llllll}50 & 1 & 0.333 & 1-> & 0\end{array}$

$66 \quad 11.000 \quad 0-->1$

node_16 --> node_12 $55 \quad 1 \quad 0.500 \quad 0$--> 1

$38 \quad 1 \quad 1.000 \quad 0 \quad-->2$

$\begin{array}{lllllll}42 & 1 & 0.200 & 1-> & 0\end{array}$

$43 \quad \begin{array}{lllll}1 & 0.250 & 0 & --> & 1\end{array}$

node_12 --> node_11 $99 \begin{array}{llllll}0.200 & 0 & -->\end{array}$

$25 \quad \begin{array}{lllll}1 & 0.500 & 0 & --> & 1\end{array}$ 


\begin{tabular}{|c|c|c|}
\hline & 31 & $\begin{array}{llll} & 0.667 & 1--> & \end{array}$ \\
\hline \multirow{3}{*}{ node_11 --> node_10 } & 8 & $10.250 \quad 1-->2$ \\
\hline & 23 & $\begin{array}{llll}1 & 1.000 & 0 & -->\end{array}$ \\
\hline & 27 & $\begin{array}{llll}1 & 0.250 & 0 & -->\end{array}$ \\
\hline \multirow[t]{5}{*}{ node_10 --> node_9 } & 4 & $\begin{array}{llll}1 & 0.200 & 0 & -->\end{array}$ \\
\hline & 15 & $\begin{array}{llll}1 & 0.250 & 0 & -->\end{array}$ \\
\hline & 35 & $10.4001-->2$ \\
\hline & 47 & $10.500 \quad 0-->1$ \\
\hline & 55 & $10.500 \quad 0-->1$ \\
\hline \multicolumn{2}{|c|}{ node_9 --> A. gavialimimus 8} & $\begin{array}{llll}1 & 0.250 & 2 & -->\end{array}$ \\
\hline & 21 & $10.400 \quad 0 \quad-->2$ \\
\hline & 41 & $10.200 \quad 0-->1$ \\
\hline & 44 & $10.250 \quad 0-->1$ \\
\hline \multirow[t]{13}{*}{ node_9 --> node_8 } & 8 & $\begin{array}{llll}1 & 0.250 & 2 & -->\end{array}$ \\
\hline & 9 & $10.2001-->0$ \\
\hline & 18 & $11.0000==>1$ \\
\hline & 21 & $10.400 \quad 0-->2$ \\
\hline & 24 & $10.286 \quad 2-->1$ \\
\hline & 36 & $10.250 \quad 0-->1$ \\
\hline & 41 & $10.200 \quad 0-->1$ \\
\hline & 42 & $10.200 \quad 0-->1$ \\
\hline & 44 & $10.250 \quad 0-->1$ \\
\hline & 49 & $10.3330-->1$ \\
\hline & 50 & $10.3330-->1$ \\
\hline & 64 & $10.500 \quad 0-->1$ \\
\hline & 65 & $10.500 \quad 0-->1$ \\
\hline node_8 --> A. kokeni & 33 & $10.2862==>0$ \\
\hline node_8 --> A. rostratum & 27 & $10.2502==>1$ \\
\hline \multirow[t]{2}{*}{ node_10 --> C. campi } & 4 & $10.200 \quad 0-->1$ \\
\hline & 15 & $\begin{array}{llll}1 & 0.250 & 0 & -->\end{array}$ \\
\hline
\end{tabular}




\begin{tabular}{|c|c|c|}
\hline & 31 & $10.6672-->0$ \\
\hline \multirow[t]{12}{*}{ node_11 --> W. elongatus } & 7 & $10.3330==>1$ \\
\hline & 8 & $\begin{array}{llll}1 & 0.250 & 1--> & 2\end{array}$ \\
\hline & 11 & $10.2500==>1$ \\
\hline & 20 & $10.3331==>2$ \\
\hline & 22 & $10.2001==>0$ \\
\hline & 23 & $\begin{array}{llll}1 & 1.000 & 0 & -->\end{array}$ \\
\hline & 27 & $10.250 \quad 0==>1$ \\
\hline & 30 & $10.5000==>1$ \\
\hline & 33 & $10.2862==>0$ \\
\hline & 35 & $\begin{array}{llll}1 & 0.400 & 1--> & 2\end{array}$ \\
\hline & 47 & $\begin{array}{llll}1 & 0.500 & 0 & -->\end{array}$ \\
\hline & 55 & $\begin{array}{llll}1 & 0.500 & 0 & -->\end{array}$ \\
\hline \multirow[t]{2}{*}{ node_12 --> S. nielseni } & 25 & $\begin{array}{llll}1 & 0.500 & 0 & -->\end{array}$ \\
\hline & 37 & $10.5000==>1$ \\
\hline \multirow[t]{11}{*}{ node_16 --> node_15 } & 5 & $10.500 \quad 0-->1$ \\
\hline & 9 & $10.200 \quad 0-->1$ \\
\hline & 11 & $10.2500==>1$ \\
\hline & 15 & $10.2500==>1$ \\
\hline & 24 & $\begin{array}{llll}1 & 0.286 & 2 & -->\end{array}$ \\
\hline & 27 & $\begin{array}{llll}1 & 0.250 & 0 & -->\end{array}$ \\
\hline & 31 & $10.6671-->2$ \\
\hline & 38 & $\begin{array}{llll}1 & 1.000 & 0 & -->\end{array}$ \\
\hline & 42 & $10.2001-->0$ \\
\hline & 53 & $10.3331==>0$ \\
\hline & 65 & $10.500 \quad 0-->1$ \\
\hline \multirow[t]{4}{*}{ node_15 --> node_14 } & 19 & $10.2501==>0$ \\
\hline & 22 & $10.2001==>0$ \\
\hline & 55 & $\begin{array}{llll}1 & 0.500 & 0 & -->\end{array}$ \\
\hline & 58 & $10.3331==>0$ \\
\hline
\end{tabular}




\begin{tabular}{|c|c|c|}
\hline & 68 & $10.2501==>0$ \\
\hline & 69 & $10.3331==>0$ \\
\hline \multirow[t]{5}{*}{ node_14 --> node_14 } & 3 & $10.3332==>1$ \\
\hline & 4 & $10.2000==>1$ \\
\hline & 21 & $\begin{array}{llll}1 & 0.400 & 0 & -->\end{array}$ \\
\hline & 24 & $\begin{array}{llll} & 0.286 & 1--> & 2\end{array}$ \\
\hline & 61 & $\begin{array}{llll}1 & 0.500 & 0 & -->\end{array}$ \\
\hline \multirow[t]{5}{*}{ node_13 --> node_5 } & 8 & $\begin{array}{llll}1 & 0.250 & 1-->0\end{array}$ \\
\hline & 9 & $10.2001==>0$ \\
\hline & 41 & $10.2000==>1$ \\
\hline & 48 & $\begin{array}{llll}1 & 0.333 & 1-->0\end{array}$ \\
\hline & 53 & $10.3330==>1$ \\
\hline \multirow[t]{7}{*}{ node_5 --> node_4 } & 12 & $\begin{array}{llll}1 & 0.500 & 0 & -->\end{array}$ \\
\hline & 29 & $10.3331==>0$ \\
\hline & 49 & $10.3330==>1$ \\
\hline & 52 & $11.000 \quad 0 \quad-->1$ \\
\hline & 57 & $10.3331-->0$ \\
\hline & 59 & $\begin{array}{llll}1 & 0.333 & 0 & -->\end{array}$ \\
\hline & 64 & $\begin{array}{llll}1 & 0.500 & 0 & -->\end{array}$ \\
\hline \multirow[t]{2}{*}{ node_4 --> node_3 } & 27 & $\begin{array}{lll}10.250 & 2==>1\end{array}$ \\
\hline & 32 & $10.4001-->2$ \\
\hline \multirow[t]{4}{*}{ node_3 --> I. amplus } & 5 & $10.5001==>0$ \\
\hline & 22 & $10.2000==>1$ \\
\hline & 55 & $10.5001==>0$ \\
\hline & 56 & $11.0001==>0$ \\
\hline \multirow[t]{4}{*}{ node_3 --> node_2 } & 33 & $10.2862==>1$ \\
\hline & 35 & $10.4001==>0$ \\
\hline & 36 & $10.250 \quad 0==>1$ \\
\hline & 68 & $\begin{array}{llll} & 0.250 & 0 .->\end{array}$ \\
\hline
\end{tabular}

node_2 --> node_1

3

$10.3331==>0$ 


\begin{tabular}{|c|c|c|c|}
\hline & 11 & 10.250 & $1-->0$ \\
\hline & 20 & 10.333 & $1-->0$ \\
\hline \multirow[t]{11}{*}{ node_1 --> L. euri } & 1 & 10.500 & $1==>0$ \\
\hline & 4 & 10.200 & $1==>0$ \\
\hline & 20 & 10.333 & $0-->2$ \\
\hline & 24 & 10.286 & $2==>0$ \\
\hline & 27 & 10.250 & $1==>2$ \\
\hline & 41 & 10.200 & $1==>0$ \\
\hline & 42 & 10.200 & $0==>1$ \\
\hline & 43 & 10.250 & $0==>1$ \\
\hline & 45 & 10.500 & $0==>1$ \\
\hline & 48 & 10.333 & $0-->1$ \\
\hline & 55 & 10.500 & $1==>2$ \\
\hline \multirow[t]{6}{*}{ node_1 --> T. acuta } & 8 & 10.250 & $0==>2$ \\
\hline & 9 & 10.200 & $0==>1$ \\
\hline & 19 & 10.250 & $0==>1$ \\
\hline & 29 & 10.333 & $0==>1$ \\
\hline & 37 & 10.500 & $0==>1$ \\
\hline & 47 & 10.500 & $0==>1$ \\
\hline \multirow[t]{4}{*}{ node_2 --> P. depressa } & 10 & 10.500 & $0==>1$ \\
\hline & 15 & 10.250 & $1==>0$ \\
\hline & 32 & 10.400 & $2-->1$ \\
\hline & 44 & 10.250 & $0==>1$ \\
\hline \multirow[t]{5}{*}{ node_4 --> M. casei } & 2 & 10.500 & $0==>1$ \\
\hline & 8 & 10.250 & $0-->2$ \\
\hline & 10 & 10.500 & $0==>1$ \\
\hline & 25 & 10.500 & $0==>1$ \\
\hline & 33 & 10.286 & $2==>0$ \\
\hline \multirow[t]{2}{*}{ node_5 --> node_6 } & 3 & 10.333 & $1==>0$ \\
\hline & 20 & 10.333 & $1==>2$ \\
\hline
\end{tabular}




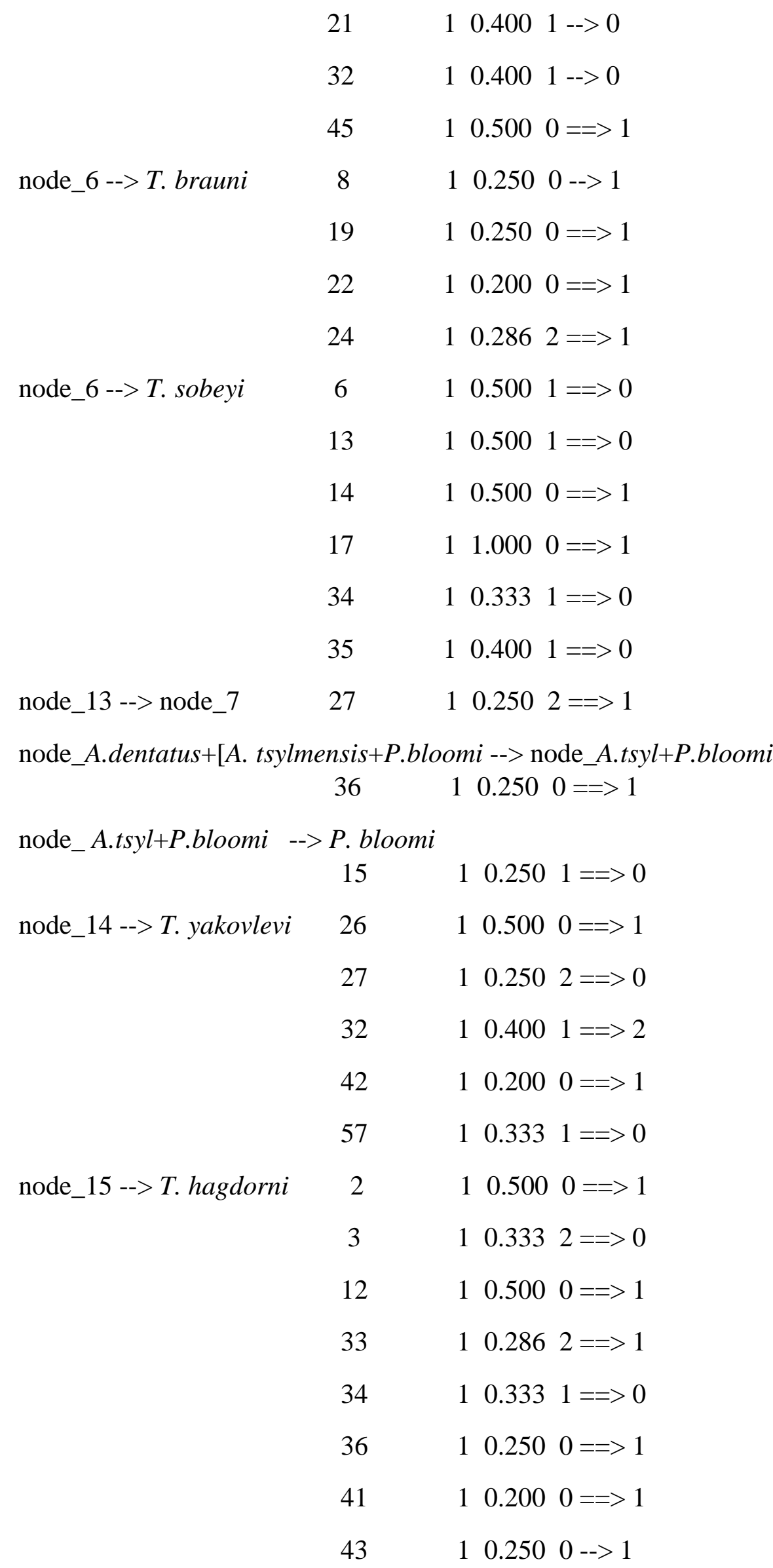


$10.3330==>1$

node_17 --> B. sushkini 8

$\begin{array}{lll}1 & 0.250 \quad 2-->1\end{array}$

$20 \quad \begin{array}{lllll}1 & 0.333 & 0 & --> & 1\end{array}$

$30 \quad 10.500 \quad 0==>1$

$32 \quad \begin{array}{lllll} & 0.400 & 0 & --> & 1\end{array}$

$43 \quad \begin{array}{lllll}1 & 0.250 & 0 & --> & 1\end{array}$

$44 \quad \begin{array}{llll}1 & 0.250 & 0 & ==>\end{array}$

$\begin{array}{lllll}50 & 1 & 0.333 & 1-->0\end{array}$

$58 \quad 10.3331==>0$

$61 \quad 10.500 \quad 0==>1$

$66 \quad 11.000 \quad 0-->1$

$68 \quad 1 \quad 0.250 \quad 1==>0$

$69 \quad 10.3331==>0$

node_18 --> E. madagascariensis $3 \quad 10.3332==>1$

$4 \quad 1 \quad 0.2001-->0$

$7 \quad 10.3330==>1$

$\begin{array}{llllll}9 & 1 & 0.200 & 0 & -->\end{array}$

$16 \quad 11.000 \quad 0==>1$

$21 \quad 10.400 \quad 0==>1$

$22 \quad \begin{array}{lllll}1 & 0.200 & 0 & -->\end{array}$

$24 \quad 10.286 \quad 2==>1$

$26 \quad \begin{array}{lll}1 & 0.500 \quad 0==>1\end{array}$

$33 \quad 10.2860==>1$

$35 \quad \begin{array}{lllll}3 & 0.400 & 0 & -->\end{array}$

$41 \quad 10.200 \quad 0==>1$

$\begin{array}{lllll}48 & 1 & 0.333 & 0 & -->\end{array}$

$\begin{array}{llllll}51 & 1 & 1.000 & 0 & -->\end{array}$

$\begin{array}{lllll}53 & 1 & 0.333 & 0 & -->\end{array}$

$54 \quad \begin{array}{lllll}1 & 1.000 & 0 & -->\end{array}$

$\begin{array}{lllll}57 & 1 & 0.333 & 0 & -->\end{array}$ 


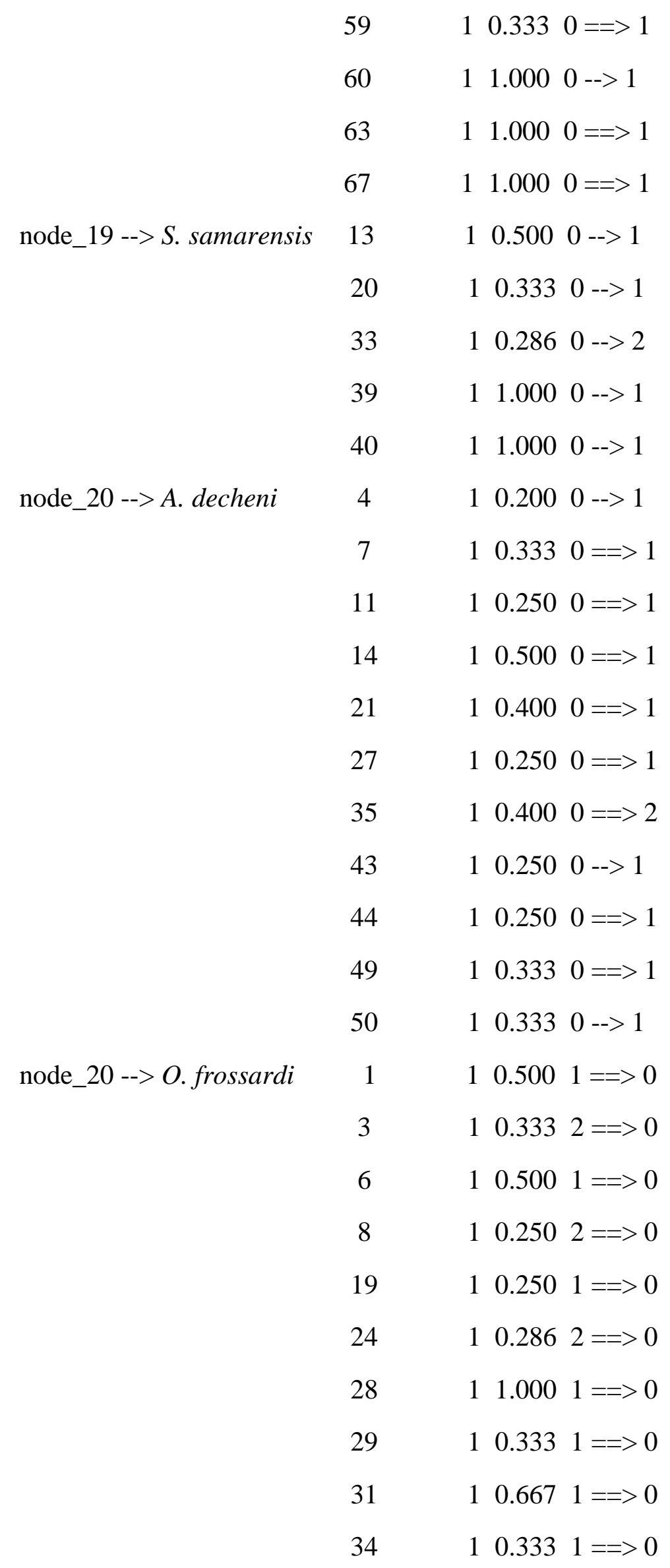




$\begin{array}{llll}42 & 1 & 0.200 & 1==>0 \\ 46 & 1 & 1.000 & 1==>0 \\ 58 & 1 & 0.333 & 1==>0 \\ 62 & 1 & 1.000 & 1==>0 \\ 68 & 1 & 0.250 & 1==>0 \\ 69 & 1 & 0.333 & 1==>0\end{array}$




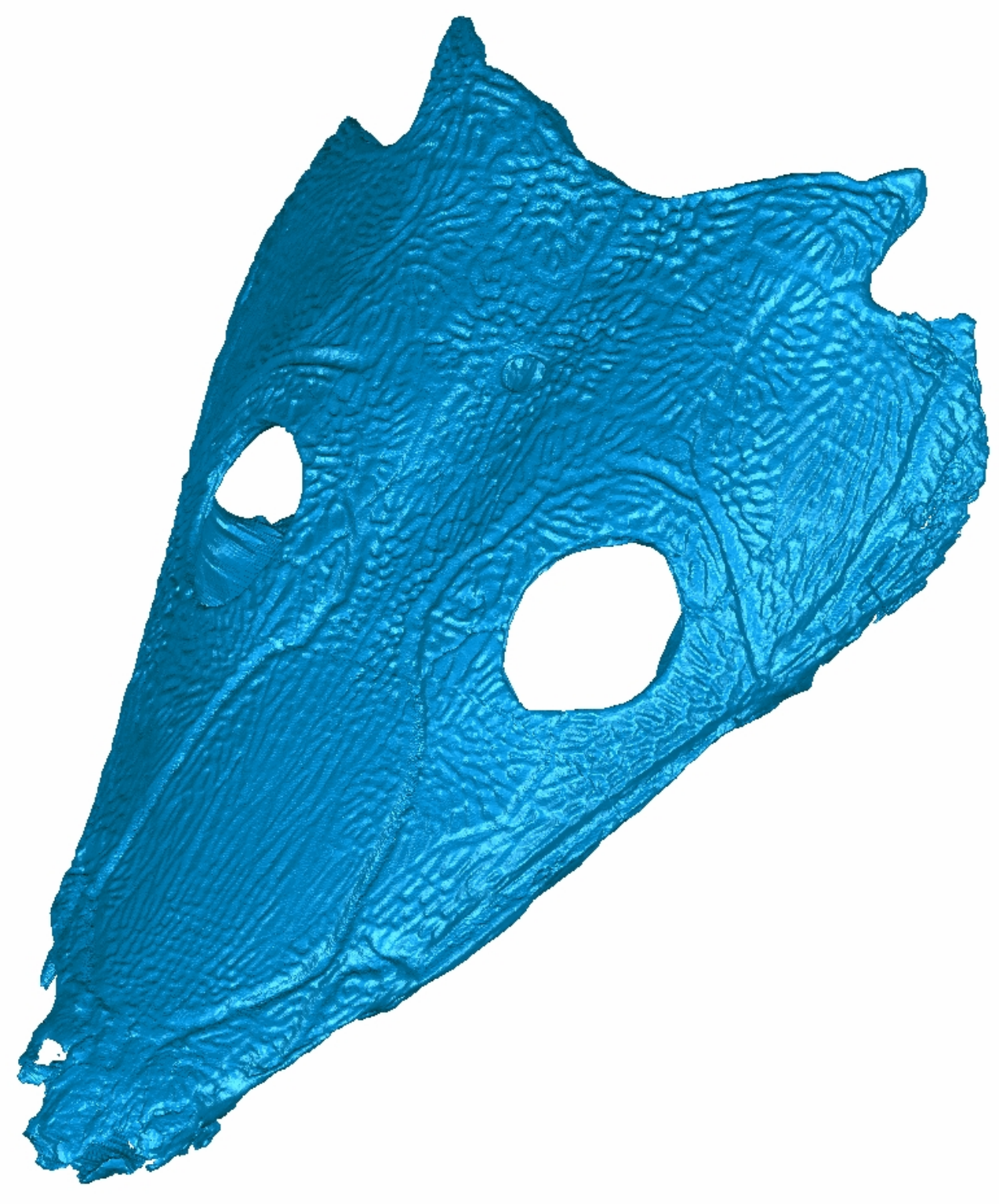

Click on the image to activate the 3D Model. 


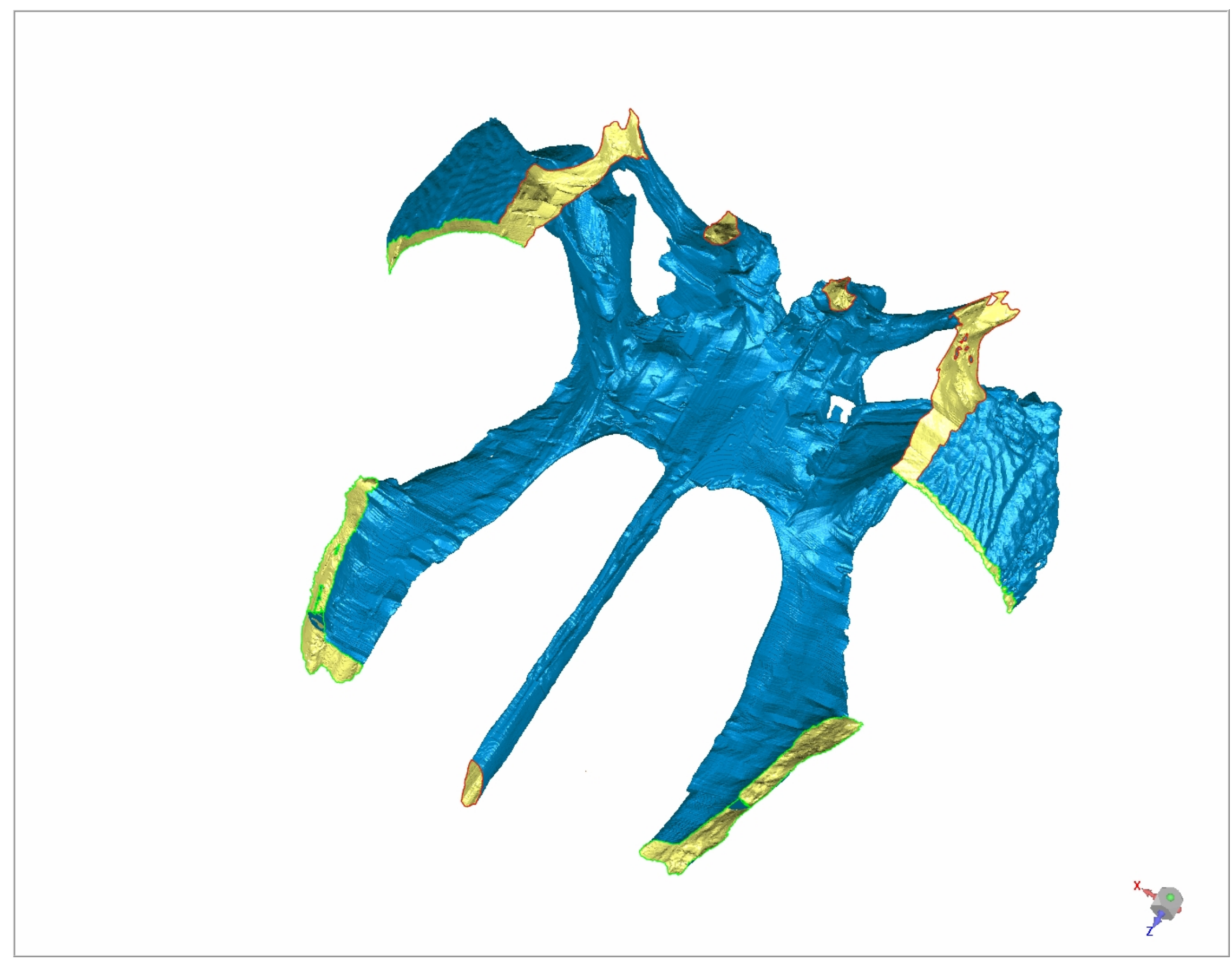

Click on the image to activate the 3D Model. 